\title{
Alberto Camplani
}

\section{Setting a Bishopric / Arranging an Archive: Traces of Archival Activity in the Bishopric of Alexandria and Antioch}

\begin{abstract}
Early Christianity was heir to the archival practice and discourse of Greek and Roman societies, in which public and private archives enjoyed a great deal of consideration. Even before creating their own archives, Christian congregations, when becoming a structured society, adhered to the archival discourse of their times, and the mention of archives in their writings served apologetic and theological aims. The article argues that the main impulse to undertake archival activity came from the new form of leadership, the bishop: alone, or in connections with other colleagues, in particular within the meetings (synods), the bishop produced a huge number of written records, which was to be arranged in archival form. After a brief presentation of the papyrological evidence, the article discusse the traces of ancient episcopal archives detectable in the historiographical and apologetic writings compiled in the main episcopal sees, such as Rome, Alexandria, and Antioch.
\end{abstract}

\section{Historical introduction and methodological issues}

Early Christianity was heir to the archival practice and discourse of Greek and Roman societies. The high amount of consideration achieved by public and private archives, ${ }^{1}$ regarded as authoritative repositories of memoirs and legal docu-

1 I will begin with a working definition of 'archive' offered by Vandorpe 2009, 217-218 in a recent handbook of papyrology, notoriously a discipline which pays great attention to the study of dossiers and archives: '[an] archive is a deliberate collection of papers in antiquity by a single person, family, community, or around an office'. Obviously, in the course of the work, I will also make use of Schenk's and Friedrich's papers and take into account the sophisticated conceptual framework they proposed at our conference: I am thinking in particular of Schenk's distinction between archival records, archives and archival thinking, and Friedrich's reconstruction of the dialectics between archival practices and archival discourse, both of which are very useful for approaching the scant clues we have about Late Antique archives. See also their books: Friedrich

https://doi.org/10.1515/9783110541397-008, (cc) BY-NC-ND (c) 2018 A. Camplani, published by De Gruyter. This work is licensed under the Creative Commons Attribution-NonCommercial-NoDerivs 3.0 License. 
ments owned by a family, a city or a state, affected Jesus' followers from the beginning of the second century CE. This was particularly true when Christianity began to conceive of itself as a structured system of congregations and as a complex society even before the birth of the monarchical episcopate. ${ }^{2}$ However, the main impulse to undertake archival activity came from the bishops themselves: from their actions within their dioceses, their relationship with the congregations and the colleagues of other cities and countries, and their official meetings (the synods), all of which produced a huge number of written records. Bishoprics and synods were an original product of the expansion and growth of the new religion, but also received and reworked models and attitudes coming from the bureaucratic offices of the Greco-Roman society, including the latter's attention to written records of collective decisions. ${ }^{3}$

For that reason, I will surmise that the evolution of the monarchical episcopate is responsible for the growth of the first Christian archives. ${ }^{4}$ My argument will be illustrated by studying some cases in which the documentation allows us to follow the development of archival activity. Despite the enormous loss of ancient Christian archives (with few exceptions, unfortunately), we know about the multiplicity of activities which could be committed to written records through other clues, such as a list of members of the clergy, a list of widows, a list of the succession of bishops, and-in dioceses owning the right to intervene in the congregations of cities and villages in the same province-a list of the subordinate bishops, which also had the ideological function of marking the communion. Another activity which could be recorded in writing was the recruitment of deacons and presbyters: the system used since the end of the third century consisted in writing a contract according to a model drawn from civil society. ${ }^{5}$ Finally, there was the transmission of letters and short messages both inside and outside the diocese, which were

2013; Schenk 2014. Interesting insights have been provided by Francia 2015 within a contribution devoted to the archives/libraries of Ninive.

2 On this process, see Gaudemet 1958, 1994.

3 Adler 2012, 919-925; Camplani 2006b.

4 I am aware of the fact that the label 'monarchical episcopate' is debated nowadays. See the documentation presented, in the framework of a new hypothesis, by Stewart 2014, who, against the general consensus on the emergence of bishops from the presbyterium responsible of a city congregation, outlines a complex evolution from original episcopoi/householders, which constituted the presbyterium of the city, and later monoepiscopoi emerging from the presbyterium. While the writing of letters between congregations is both the result of a necessity for congregations living at a certain distance and the sign of commitment to the written word per se, the archival practice takes place more easily when religious power is concentrated in one person.

5 Wipszycka 1996. 
addressed to other congregations and bishops, as well as the activity of the synods, whose development is strictly tied to the growing power of the monarchical bishop: the meetings organised in major cities to discuss important issues involved the tachygraphic transcription of debates, recording what the participants said, redacting synodical letters and providing a synthesis of the decisions made; in some cases, this even took the form of canons. ${ }^{6}$

All this documentation can only be classified as archival records if we are certain of the existence of archives. Since these are mentioned in the sources, but are lost for the most part, our first task is that of collecting evidence about the concrete situations in which it was felt necessary to record something in writing, while our second task is that of comparing the data with the information given by the sources about either archives or the persons working in them. ${ }^{7}$ This is not exactly the same as studying literacy in relation to the history of the book in Christian congregations, as proposed by Gamble. ${ }^{8}$ The kind of documentation preserved in episcopal archives is normally more practical and more linked to the necessities of communal life, although it is impossible to draw a clear line between a literary document and a document with a more practical function-a letter of recommendation can be classified as both a literary text and an archival record, for example. Much depends on the function it plays in the context in which it is preserved and used.

Of course, we should prioritise the issue of literacy in Christian congregations, which have been at the centre of current research and led to some interesting but questionable results. Gamble, Norelli and Bagnall are only a few of the members of a large group of scholars who have been devoting their time and energy to studying ancient information about books, libraries and archives. ${ }^{9}$ I am aware of the fact

6 Hess 2002, 5-88; Bernardini 2009, 34-58.

7 It often happens that literary, epigraphic or papyrological sources, witnesses to diverse historical situations, give us information about the personnel working in an archive without clearly referring to the existence of the latter. This kind of information is also to be taken into account for the history of Christian archives.

8 See Gamble 1995, whose first chapter (pp. 1-41) has the title 'Literacy and literary culture in early Christianity'. Of course, things are very complicated, since early Christian documents all had a more or less pronounced practical function. 'Early Christian letters, however, have often been described as nonliterary, either by denying that letters were a form of literature proper (Overbeck) or by locating the analogues of Christian letters in the ordinary private letters of the papyri (Deissmann)' (36). The conclusion by Gamble is that 'the letters found in the New Testament and among the Apostolic Fathers do not, as a group, closely resemble either the private letters among the papyri or the literary letters of the elite but fall between these extremes of epistolary practice' (37).

9 Gamble 1995, 28-40 (orality and literary culture), 144-161 (early Christian libraries); Norelli 2006, 8-13 ('Comunicazione scritta e comunicazione orale'); Bagnall 2009. 
that, on the one hand, the relationship between Jesus and books, or rather scrolls, and more generally between Jesus and the written word-what we would call 'literacy'-is a problematic one, which cannot be answered positively or negatively, but it deserves a complex approach in which his attitude to the written heritage of Judaism and the Bible should be taken into account and put in relation to his strong tendency to transmit his message orally. On the other hand, this tension-this problematic attitude to the written word-should be considered in terms of its influence on the future development of the diverse congregations which were formed after his death: just a few years later, we find Paul of Tarsus elaborating on a different mentality regarding the written word, but the very diverse streams of Jesus' followers were not all ready to agree with him. How relevant is this question to the history of Christian archives?

The purpose of my paper is both to define some of the methodological problems involved in the reconstruction of the episcopal archives of Late Antiquity and to explore the possible correlation between the birth and subsequent evolution of the bishoprics in the traditional sense of the term and the constitution of archives. I think that an indirect correlation may be established in the sense that an archive could be arranged more easily in a unitary congregation led by a monarchical bishop at the end of the second century or beginning of the third than in a presbyteral federation of diverse congregations typical of the first two centuries. The documentation at our disposal supports the former hypothesis. ${ }^{10}$ My perspective is obviously that of a historian of Christianity, as may be inferred from the following questions: How did the evolution of Christianity in the eastern Mediterranean involve the formation of a particular type of archive that connected with the practical, cultural and liturgical activities carried out by congregations of believers? When did the transition take place from one form of religion in which orality played a relevant role and on which communal life was based, only to a lesser extent on the writing, reading and editing of texts and documents, to a set of congregations that not only gave significant weight to the written word and the book, but also relied on writing for a good part of their practical activities? In sum, on the one hand there is a problem of methodology and analysis of the sources concerning the recovery of archives, and on the other there is an issue of a historical type. ${ }^{11}$

Marginally we have to note that our quest for archives and archival culture in the past is largely dependent on the fact that we are heirs to the archival discourse and archival practices of the Mediterranean world of Late Antiquity, medieval and modern times as well as of other regions which eventually came into contact with

10 See Bagnall 2009, chapter I.

11 On this transformation, see Norelli 2012. 
it. Is there a clear case of continuity of archival activity in bishoprics from Late Antiquity up to the present day? Given what I have said about the loss of archives, the answer should be negative. An exception has been indicated by Gianfranco Fiaccadori on many occasions, however: the archiepiscopal archives of Ravenna, ${ }^{12}$ which should be studied from this perspective.

Since this paper will not only touch on early dioceses of a small size, but also on the ones situated in the largest cities in the eastern Mediterranean world in Late Antiquity, it seems appropriate to me to offer a further methodological observation here: from the theoretical point of view, we can distinguish in the activities of a large diocese, such as that of Rome or Alexandria or Antioch, three entities having a strict relationship with written records of all kinds: the chancery of the bishopric, the archive and the library. In fact, none of the information we have at our disposal corresponds to this distinction or corroborates it in a clear fashion. Perhaps there was only one place, or a system of private places, in which the written materials were prepared, and then the staff employed the single items for the different functions corresponding to our distinction of chancery, archive and library. This applies to Alexandria and Antioch as well as to Rome. ${ }^{13}$

\subsection{The myth: the archives of Rome and Edessa between bureaucratic reality and religious idealisation}

Before facing the question of the extant papyrological archives and the issue of the recovery of lost ones, I would like to highlight how the image of efficient archives affected Christian intellectuals of the first centuries on the basis of a recent and intelligent recognition by Adler:

But whether figurative or real, the terminology of Josephus and early Christian authors shows in any case how the ancient idealization of the archive has seeped into Jewish and Christian discourse about the authority of their sacred texts. ${ }^{14}$

Here we are facing the question of the archival discourse, which feeds on archival practice: the role of archives was so important in the society in which Christianity

12 Fiaccadori 2014, 244; Montanari 1992, 274-275, 281. Gianfranco Fiaccadori, who has passed away in the meantime, stressed this fact during the debates at our conference.

13 Also from a papyrological point of view, 'the term archive is clearly reserved for documentary groups of texts, whereas a public or personal library is a collection of literary texts. Works of literature may, however, be included among documentary papers': Vandorpe 2009, 218.

14 Adler 2012, 928; see also Adler 2013, 48-52. 
was spreading that some intellectuals used the reference to them as an argument in their apologetic or theological discourse. Tertullian, for instance, claims that Rome's public archives (instrumenta) confirmed the Gospel account about the tremendous events that accompanied the crucifixion of Christ; and against Marcion, he maintains that Jesus' enrolment in the Roman census was certified in these same archives. ${ }^{15}$ One of the most famous and metaphorical occurrences of the term is preserved in Ignatius' Letter to the Philadelphians: ${ }^{16}$

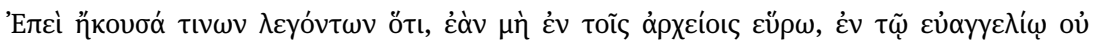

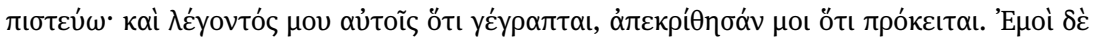

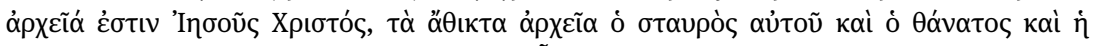

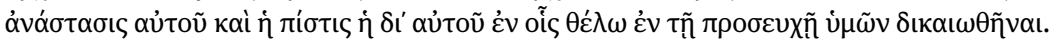

I heard someone saying: 'If I can't find it in the archives, then I won't believe [it if it's] in the Gospel'. Since I said to them: 'It is written', they replied 'This is the question'. For me, the archives are Jesus Christ, undefiled archives are his cross, and death, and resurrection, and the faith which is by him; through this I want to be justified in your prayers.

To Ignatius' adversaries, archives were the certification of theological and Christological truth. By 'archives' they meant the Old Testament, without which, according to them, nothing could be said about Christ. In his response, Ignatius seems to stress the sufficiency of Christian archives, which are not the written Gospel here, but the person of Jesus Christ. ${ }^{17}$ So, we have a double metaphoric process in this case: archives are a metaphor for the Jewish Scriptures, and, at a higher level, for the incarnate humanity of Christ, which in turn is both in continuity with the Jewish Scriptures and their fulfilment / overcoming. ${ }^{18}$

When exploring the impact of the archival ideology in the Mediterranean world and the metaphoric use of the word 'archives', Edessa comes to our attention mainly thanks to the centrality that the city achieves in Eusebius's account of the evangelisation of Osrhoene. A brief review of this account, which is shared by all its basic witnesses (Eusebius's account, a later Syriac reworking and other texts), is in order now. Abgar V, king of Edessa, is said to have sent some envoys to Palestine with a letter addressed to Jesus at the very moment of the Passion, asking him to come to Edessa in order to heal him from a serious illness. Jesus responded with a message in which he declared that it was impossible for him to make a personal visit to the king, while promising to send a disciple to Edessa

\footnotetext{
15 Apologeticum 21,19; Contra Marcionem 4,7,7.

16 Ign. Ad Philadelphos, 8,2, ed. Simonetti 2010, 402-403.

17 See Norelli 2001, 237-243.

18 Simonetti 2010, 603-605 (commentary).
} 
after his ascent into heaven, who would heal Abgar and preach the Gospel in his city. This promise was subsequently kept. The story relates the presence of a disciple of Jesus at Edessa, his working miracles and his dealings with Abgar. Such is the sequence of events related by both the Syriac source, whose Greek translation Eusebius inserted in Historia ecclesiatica (h.e.) and a later reworking of it entitled Teaching of Addai (which claims to have been written by the scribe Labubna), ${ }^{19}$ as well as implied by the Itinerarium Egeriae (17,2 and 19,2-19) and other later texts. In Eusebius h.e. I 13 we find the following statement:

\begin{abstract}
There is also documentary evidence of these things taken from the archives at Edessa which was at that time a capital city. At least, in the public documents there, which contain the things done in antiquity and at the time of Abgar, these things too are found preserved from that time to this; but there is nothing equal to hearing the letters themselves, which we have extracted from the archives, and when translated from the Syriac they are verbally as follows. ${ }^{20}$
\end{abstract}

As the reader can understand, the case of Edessa is extremely important for our enquiry, because it shows at once the historical reality of an archival culture since the establishment of an independent kingdom and above all during the Roman domination, and its mythical reworking by a Christian congregation which feels the need to connect itself to an idealised past of the kingdom with its glorious bureaucracy. The reference to the archives has been reworked in the later Teaching of Addai:

As is the custom in the kingdom of King Abgar and in all kingdoms, everything which is said before him is written and placed among the records (bēt 'ühdānā). Labubna the son of Senaq the son of Abshadar, the scribe of the king, therefore, wrote the things concerning the Apostle Addai from the beginning to the end, while Hanan, the faithful archivist (țabūlārā) of the king, set the hand of witness and placed it among the records (bèt 'ūhdānā) of the royal books, where the statutes and ordinances are placed. The matters belonging to those who buy and sell are also kept there with care and concern. ${ }^{21}$

Here we have a realistic description of Edessa's civil archives, written by a person who was familiar with them. We meet this same phenomenon in the Acts of Sharbil: in this fictional account, it is said that the archives were in front of the great altar of the city and that the exceptors wrote these acts (hypomnemata) on parch-

19 The text was first published by Phillips in 1876 and is now available with a new English translation in Howard 1981. See Desreumeaux 1993, Brock 1992-1999.

20 Eus., h.e. I 13. Edition in Schwartz and Mommsen 1999 (1903), translation in Lake 1926, 87.

21 Howard 1981, 104-107. 
ment (qartisiē) and put them in the archives (bèt arkē), where the royal parchments (qarțisē d-malkē) were preserved. According to Debié, 'le texte littéraire des Actes se présente un peu comme un document double, le texte étant le document (la scriptura interior scellée) tandis que la signature et l'attestation par le scribe et les témoins constituent la "couverture" (la partie supérieure avec la scriptura exterior, que l'on trouvait normalement sur le dessus des parchemins ou papyri) qui assure l'authentification'.22 There are important witnesses to these archives and to the presence of personnel taking care of them: according to Debié, the staff were trained in different writing systems of Aramaic / Syriac, which were adapted to the diverse contexts and functions the documents were intended for. ${ }^{23}$

A document has been published that was explicitly meant for depositing in the archive ('arkîwn, transcription of '́pxcĩov) of the 'renowned city of Edessa', viz. a contract for the sale of a slave girl (P.Dura 28), dating to 243 CE. At the head of the text there is a memorandum describing the delivery of the document to the master of taxes 'by courier'. ${ }^{24}$

In Chronicon edessenum we find another allusion to Edessene archives, from which an account was drawn about the famous flood of 201:25 'In the year 513 in the reign of [Septimius] Severus and the reign of King Abgar, son of King Ma'nu, in the month of the latter Teshrin, the spring of water that comes forth from the great palace of King Abgar the Great became abundant'. This incipit is followed by the description of the flood and the reaction of the public authorities and population. At the end we read:

Maryahb son of Shemesh and Qayoma son of Magratat - these scribes (sāprē) of Edessa wrote down this event at the order of King Abgar, and Bardin and Bulid who were in charge of the archives ('arkîwn = $\dot{\alpha} \rho \chi \varepsilon \tilde{o}$ ) ) of Edessa received it and placed it inside them as šarrīre of the city.

From the narrative, it becomes evident that one of the motives for including the whole story in the archives is exemption from taxes for a period of time that the king granted to those whose property had been damaged by flooding. This was one of the main functions of a civil archive: to preserve official decisions concerning taxes, military movements and the reorganisation of civil administration. ${ }^{26}$

22 Debié 2015, 171.

23 Debié 2015, 167.

24 Adler 2012, 930-931; Debié 2015, 168-169.

25 Ross 2001, 104-107, with a translation by Segal 1970, 24-25. Edition in Guidi 1903, 1-3.

26 Debié 2015, 359-360. 
Debié has ably demonstrated how much the use of archives and ephemerides influenced historical writing in the Syriac language. ${ }^{27}$

It must be observed that while there is a real reference to public archives in the examples presented here, in Eusebius's translation of the old Syriac text and in the Teaching of Addai the reference should be considered fictional. As I wrote some years ago, there is no serious witness to the obsessively repeated claim that the Doctrina Addai derives from the archives of Edessa rather than from those of the church there. The legend's absence from both the city's first documentary histories written by Christian authors as of the sixth century, with the exception of Joshua the Stylite, and from the works by Jacob of Edessa is worthy of note. ${ }^{28}$ This sheds light upon the ideological character of both the Eusebian narrative and the Teaching, calling into question the historical reality of a connection between the legend and the Edessene archives. We are dealing here with a propagandistic leitmotiv: already present within the Syriac text known to Eusebius, this would then have been further emphasised by the Teaching in order to confer greater authority upon the story. This leitmotiv was reproduced by Eusebius for reasons that are patently apologetic in nature. ${ }^{29}$

According to Adler, the English translation of Eusebius's passage like the one proposed above has done great harm to the historian's credibility: 'accepting it would mean that Eusebius expects us to believe that he: (1) travelled to Edessa; (2) retrieved the relevant Syriac documents from the archives; and (3) either translated them into Greek himself or had them translated into Greek for him'.$^{30}$ The

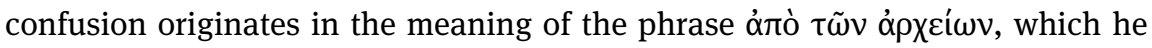
proposes to translate as 'ancient records' instead of 'archives': in this particular expression, Eusebius is not referring to Edessa's archives as in the above sentence, but rather to a longer text, the old Syriac version from which he has extracted Jesus' and Abgar's correspondence. ${ }^{31}$ This could be written on the model

27 Debié 2015, 358-367: 'Les chroniques d'Édesse ont conservé l'enregistrement des constructions et des dons aux églises de la ville' (364); 'Les chancelleries des métropoles et des patriarches produisaient ou recevaient aussi des documents qui étaient classés et enregistrés: correspondances, actes des synodes, listes des ordinations, entrée en fonction et décès au moins des patriarches et des évêques. Les chroniques ont conservés les listes de succession des évêques des villes dont elles écrivaient l'histoire' (365). On Moses of Khorene's mention of the archives of Nisibis and Edessa, see Traina 1996.

28 Van Rompay 1999.

29 Camplani 2009b.

30 Adler 2012, 936.

31 Adler 2012, 937. Adler proposes to tie the mention of the act of extracting the account from

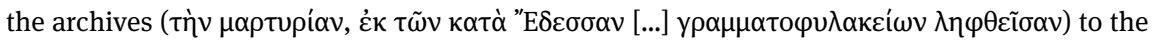


of the day book or register, in use since the time of Alexander the Great (who in turn inherited a Persian custom), composed of royal decrees, correspondence and acts; in Edessa it was called the ktābā d-bēt arke..$^{32}$

In conclusion, Edessa's elite was proud of the state archival practices, thanks to a well-trained bureaucracy, and was able to build an archival discourse to the point that the reference to public archives was used to build fictional pieces of literature outlining the origins of the Christian congregation. We have no way of knowing if the documents produced in the everyday life of the Edessene congregation were preserved in public archives or in those of the bishopric, which seems more likely, and if the two, after the 'peace' of the Church, were merged into a single archive or remained independent of each other. What we do know is that the Edessene elite was legitimising its Christian history with the mention of state archives that past generations had helped to create.

\subsection{Early archival activity and the bishops}

We have no archive arranged by the leading figures of early Christianity, such as prophets, apostles, preachers or didaskaloi, nor are we informed about their archival activity. ${ }^{33}$ This is not to say that written communications were lacking in Christian congregations, however-Clement of Rome's first epistle to the Corinthians is a clear indication of the contrary. ${ }^{34}$ Both here and in other early Christian writings, we find clues about gatherings of leaders for the purpose of sending and receiving texts and letters. These communications are not evidence of an archival practice, though.

On the other hand, we may follow the slow affirmation during the second century of more structured congregations led by groups of presbyters, among which one individual emerges, the bishop, according to a very controversial process

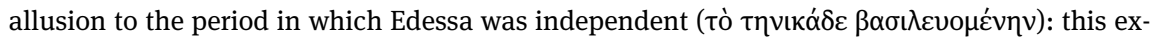
pression would be a reference not to the time of Abgar V, but to a later period, and consequently the act of extracting was done by someone in the third century, before Edessa's transformation

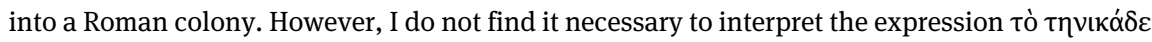
$\beta \alpha \sigma \iota \lambda \varepsilon v o \mu \varepsilon \dot{v} \eta v$ in connection with the act of extracting the story; it is preferable to refer it directly to Abgar V, who is the protagonist of the account; this same expression is used by Eusebius when, after narrating the vicissitude of Paul of Samosata, he alludes to Aurelian's attitude to-

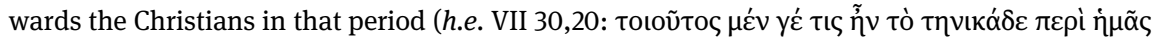

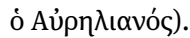

32 Adler 2012, 936; Debié 2015, 171-172.

33 This also applies to Montanism; see Eus. h.e. V 16-19.

34 See the detailed discussion in Prinzivalli 2010. 
which has been discussed in a recent book by Alastair Stewart. ${ }^{35}$ It is in relation to this process that some clues begin to appear in our sources pointing to an archival practice.

However, it is only with (1) Eusebius's repeated allusion to the preservation of documentation stemming from gatherings of presbyters and bishops since the second half of the second century (synods), ${ }^{36}(2)$ the clues about the chancery's activity in Carthage that are detectable in Tertullian's works and Cyprian's correspondence, ${ }^{37}$ and (3) the tachygraphic transcription of sentences uttered by the bishops at the synod in $256,{ }^{38}$ that we have the possibility to assume the existence of archives, although we do not possess a clear statement to that effect. In particular, the huge amounts of documentation produced by the synods, the diverse typology of their written statements (the tachygraphic transcription of the sententiae of the participants, which were edited by the process of emendatio so as to achieve the form of gesta ecclesiastica), synodical letters expressing the synthesis of such debates, libelli recording all the decisions taken (which would eventually lead to the canons), and the cross-references detectable among them are all clear signs of the fact that the correlation between the new leadership of the monarchical bishop and the spreading of synodical activity is the historical factor that gave impetus to the growth of Christian archives.

We get indirect confirmation about the importance of bishops for the growth of the archival practice in Christian congregations from Bagnall's suggestion that most of the early literary papyri from Egypt, which is normally dated to the second century, is connected to the existence of bishops along the Nile, who are not, in fact, attested before the end of the second century or the beginning of the third. ${ }^{39}$ Documentary papyri relating to the Christian congregations are even later. ${ }^{40}$ That means that libraries and archives, which were not clearly distinguished, especially in small or medium-size dioceses, were established when the leadership of the local congregation was put in the hands of a bishop. In a sense, the new archives were a reflection of a structure that was becoming more and more complex, but at the same time dominated by increasingly autocratic leaders.

35 Stewart 2014.

36 Camplani 2006b and Hess 2002. See in particular Eusebius, h.e. V 16,23-28 (synods against the Montanists and the Quartodecimans) and VII 27,1-30,17 (synods against Berillus and Paul of Samosata).

37 Duval 2000.

38 See in particular Bernardini 2009, 191-201, one of the finest studies on early Christian synods and their documentation, and Munier 1974, V-VI.

39 Bagnall 2009, 1-24, discussed in Wipszycka 2015, 64-66.

40 Luijendijk 2008. 


\subsection{The papyrological evidence}

Some ecclesiastical archives have been preserved in papyri, recovered through systematic excavation or through chance discovery. In the latter case, archives were often divided into lots by the finders and then acquired by different institutions, so one of the tasks of the papyrologists is to ascertain whether the documents belonged to a specific archive or not. However, apart from the question of recovering the archives, it is important to observe that documentary papyri are of the highest importance if we want to understand the Church's attitude to written records of any kind. On the basis of the papyrological discoveries it is becoming evident, as has been stressed by Ewa Wipszycka, that in the process of forming its institutions,

the church imitated both the Roman state administration and that of the large estates. It took over from them the habit of putting all sorts of matters into writing. The chancellery of the bishop produced Greek and Coptic documents accompanying and documenting the various activities of the church. When the bishop ordained presbyters or deacons, they gave him written declarations by which they pledged themselves not to leave their diocese, to take care of the church which had been entrusted to them, to fast on the prescribed days, to learn by heart some biblical texts (the Gospels, Paul's Epistles, the Psalms), and so on. In some cases the newly ordained presbyters or deacons handed to the bishop written declarations signed by local notables who vouched for their future good behaviour. When charging one of his subordinates with visiting a church, the bishop gave him a warrant. Examples could be easily multiplied. The earliest piece of evidence we have concerning the ecclesiastical habit of committing all sorts of things to writing is the papyrus $C P R \mathrm{~V} 11^{41}$ of the beginning of the fourth century: here a newly ordained deacon binds himself not to leave the bishop. Functioning in this way, church institutions both implied and favoured literacy among the clergy, ${ }^{42}$

and, we could add, supported the formation of archives.

Two books, by Luijendijk and Blummel, will help us in our approach to the first letters preserved on papyrus. ${ }^{43}$ Some of them are connected to Sotas, a person whom Luijendijk has proposed to identify with the bishop of Oxyrhynchus in the second half of the third century. This hypothesis has been confirmed by the historiographical text preserved in an Ethiopic manuscript which is being edited by Alessandro Bausi and commented by myself. ${ }^{44} \mathrm{I}$ do not know if it is possible to

41 Edition, Italian translation and commentary in Wipszycka 1996.

42 Wipszycka 2015, 121-122, reproducing Wipszycka 2007, 343.

43 Luijendijk 2008, 81-151; Blumell/Wayment 2015, 463-487.

44 See Bausi/Camplani 2013, 247 and the editio minor in 2016, 249-302. In Blumell/Wayment 2015, 479, the statement that the new Ethiopic text is contained in an 'Ethiopic ms that dates to 
surmise that the letters connected with Sotas of Oxyrhynchus were part of an archive-Luijendijk maintains a degree of caution about this question. ${ }^{45}$ What is particularly interesting is the exceptional fact that two of them are preserved on parchment, which was normally reserved for literary manuscripts and rarely used for documents: 'Behind a material detail-these two seemingly insignificant parchment scraps-I behold the contours of a Christian scriptorium at Oxyrhynchus', she says. ${ }^{46}$ This high level of literacy is the first condition for the formation of an episcopal archive.

The largest group of archives comes from monastic groups, the oldest of which are dated to the fourth century. ${ }^{47}$ The study of ecclesiastical archives is mainly linked with two names: Abraham, bishop of Hermonthis, and Pisenthius, bishop of Keft, who lived between the sixth and the seventh centuries. ${ }^{48}$ They are currently at the centre of scholarly attention, because their rich archives need to be edited or partially re-edited. ${ }^{49}$

Abraham's archive was discovered in the monastery of Phoibammon built into the temple of Hatshepsut at Dayr al-Bahari, where he resided for a time around 600, acting as both bishop of Hermonthis and abbot of this monastery. From the archive, a provisional edition of which has been provided in Martin Krause's dissertation, we infer that he exchanged extensive correspondence with the believers in his diocese, both clerical and secular. According to Crum: ${ }^{50}$

We see the bishop ordaining readers, deacons and priests to particular cures and formally entrusting them with their duties; arranging for the performance of service[s] in various churches, sometimes at the application of the local authorities; issuing charges on liturgical

the Aksumite age (IV-VII)' needs to be corrected to 'Ethiopic ms that dates to at least the thirteenth century, if not earlier'. In fact, the Aksumite age is the period in which the historiographical text was translated from Greek to Ge'ez and not the date of the manuscript itself. As for the Alexandrian bishop who appointed Sotas, this was not 'Theonas', as indicated, but 'Maximos'. 45 Luijendijk 2008, 89-90: 'If these papyri indeed refer to one and the same man, how do they fit together? Did they form part of an archive or is it sheer serendipity that several letters from the same person have been preserved? [...] Did Sotas store these letters in such an archive? [...] Based on the archaeology alone, we cannot determine whether these texts constitute the remains of Sota's deliberately organised documents in the strict sense of the word "archive".

46 Luijendijk 2008, 150-151; a discussion of the problem is on pp. 144-151.

47 For a list, see Giorda 2007, and Schmelz 2002, 6-14.

48 For a first approach, see the updated introduction by Wipszycka 2015, 34-41, which presents the significant advantage of looking at the two archives with the eyes of a historian.

49 For more on Abraham, it is necessary to consult Crum 1902 and Krause 1956, 1991a, 1991b; for Pisenthius, apart from the old edition by Revillout 1900-1914, see Van der Vliet 2002, 2013, 2015, and Dekker 2011.

50 Crum 1902, xvii. 
questions and edicts of interdict and excommunication against individuals and villages; dealing with vagrant priests; hearing depositions and giving judgment in local suits and communicating with the magistracy; dispensing or recommending charity. In certain functions the bishop could be replaced by the archpriest who had, for instance, powers of excommunication or interdict. The bishop's decisions might be promulgated through him; he transmits the patriarchal Festal Epistle to the clergy. The archpriest sometimes appears as attached to a particular church.

Both in Abraham's and in Pisenthius' archives we find a rich typology of documents, as can be inferred from the following select list:

- documents concerning the ordination of deacons and priests;

- documents relating to appointments to offices, including a form through which deacons were named as titular heads of churches;

- exclusion from communion of secular and clerical believers until they came to the bishop;

- requests for pardons addressed to the bishop;

- circular letters about public worship and the celebration of communion (for instance, the mention of the wafers necessary for the celebration inspected and blessed by the bishop, or of the mixing of water and wine for the chalice in the correct proportions, according to the canons; the order to other members of the clergy to administer communion temporarily in the absence of the usual clergymen, etc.); provisions for baptism and marriage;

- circular letters about sexual morality and philanthropy towards the poor;

- documents in which the bishop appears as a mediator between two parties;

- (especially in Pisenthius' archive) letters addressed to other bishops in the country;

- contracts (leases, purchase contracts, employment contracts, etc.);

- receipts;

- lists of objects;

- guarantees;

- donations;

- wills.

In these archives, we rarely find documents concerning international Church affairs and ecclesiological and theological issues or allusions to them. ${ }^{51}$ These are matters reserved for large archives located in major cities, to which we will now turn our attention.

51 One exception is the document concerning the Eucharist published in Camplani 2012, whose provenance from an archive is doubtful. 


\section{The lost archives of Alexandria and Antioch}

We have to face the problem of recovering lost church archives kept in important cities, preserving information about the clergy, buildings, the economy and, above all, major inter-diocesan affairs and the Church's relationship with the political sphere.

How can we establish whether documents in Christian writings or narratives may be attributed to church archives? It is not very easy to infer this, and a high degree of subjectivity is involved in this kind of research. First of all, we should mention the claims made by authors, redactors and scribes that a certain document or narrative is from an archivium. Not all of these claims are to be trusted, because they are often formulated to lend authority to a certain vision of things, as we have seen in the case of Edessa. However, we are often in a position to assess their credibility by way of analysis of style and comparison of documents: there are chronicles exhibiting clear signs of having been drawn from commentaria, or lists of various sorts, which could be preserved in private or congregational archives; if a sequence of documents, or the reference to a sequence of documents, occurs in a similar way in more than one historiographical writing or canonical collection, then there is a high degree of probability it is connected to official or private Christian archives. ${ }^{52}$

Although the eastern Mediterranean world is the focus of my attention here, a brief mention of Rome's church chancery and archives is unavoidable for the simple reason that I do not rule out the fact that they could have influenced Alexandrian and Antiochene church archives. These archives have raised long debates among scholars concerning their antiquity and their concrete way of functioning. In sum, looking at the issues concerning Roman archives means achieving greater awareness of the methodological problems involved in the reconstruction of the archives of other cities. ${ }^{53}$

The sources concerning Rome are not rich in information about archives and the personnel working in them for the fourth century. We know of the existence of a chartarium (also called a scrinium), ${ }^{54}$ but it is unclear whether this was an archive

52 On the relationship between archives and historiographical production, see Van Nuffelen 2004 and Burgess 2013.

53 The bibliography on the subject is very extensive: a good discussion is in Moreau 2012a, 177242; Martello 2012, 33-104; and Dalmon 2015, 109-168. The latter criticises reconstructions of church archives excessively influenced by the image we have of the imperial chancery and archives.

54 See Jerome, Adv. Rufin. 20; Leo, Epist. 69,1 (scrinia); Simplicius, Epist. 58 (scriniis). See the discussion of these passages in Dalmon 2015, 145-146. 
or a private collection. For the period of Pope Damasus, scholars are generally confident that forms of archival storage were practised, although there is no consensus about the modalities and the places involved, as has been illustrated by Dominic Moreau. ${ }^{55}$ In a first phase, there may not have been an official archive of the bishopric as such, but private places and libraries were used whose items could be connected by individuals who were familiar with their contents. What is important from our point of view is that this network of minor repositories was thought to serve an archival purpose in the fourth century.

A source like the famous Liber pontificalis (beginning of the sixth century) gives us a number of details about the personnel involved, but this information needs to be evaluated critically: organised as a series of biographies of Roman bishops from the apostle Peter onwards, the Liber is interested in documenting the history of the bureaucratic traditions of its milieu, giving them great antiquity. ${ }^{56}$

We know from the Liber and other earlier writings (of the late fourth century) of the existence of notarii, ${ }^{57}$ a term which originally denoted both the scribes devoted to the reproduction of documents and experts on juridical matters; in a second moment, the first charge is often but not always expressed by the word exceptor. In the course of time, the organisation of notarii became a complex hierarchy, so that through the sources we see other leading figures emerging in the bureaucratic organisation: exceptor, primicerius, secundicerius and notarius regionarius. ${ }^{58}$ In later redactions of the Liber pontificalis, we observe the tendency to stress the antiquity of the notarii, as in the famous passage in which their juridical role is anachronistically attributed to the era of Pope Julius II:

Fuit autem temporibus Constantini filii Constantini heretici a consulatu Feliciani et Maximini. [...] Hic constitutum fecit ut nullus clericus causam quamlibet in publico ageret, nisi in ecclesia, et notitia quae omnibus pro fide ecclesiastica est per notarios colligeretur, et omnia monumenta in ecclesia per primicerium notariorum confectio celebraretur, sive cautiones vel extrumenta aut donationes vel conmutationes vel traditiones aut testamenta vel allegationes aut manumissiones, clerici in ecclesia per scrinium sanctum celebrarentur (I 36). ${ }^{59}$

55 Moreau 2010 and 2012b. On the relationship between historiography and epistolography, see Moreau 2015.

56 See Verardi 2016, 31-80 for a full discussion of the redactional problems of the work.

57 One of the first occurrences of the term is connected to the Council of Ephesus held in 431:

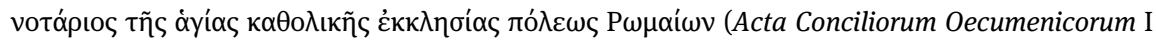
1,3.54.19).

58 Martello 2012, 33-103.

59 Duchesne 1886-1892, 205 ll. 1-2, 5-9. 
Having checked not only the sources of this passage (the so-called Liberian Catalogue) but also the parallel epitomes, which are based on more ancient editions of Liber Pontificalis, we can conclude that the development on notarii is an interpolation. ${ }^{60}$ Who was responsible for this addition? Actually, it is likely it was the notarii themselves, who, probably acting after 530, wanted their presence and activity to be reported to ancient times, up to the the era of Julius II, in order to promote the idea that they had not only been important in the development of the Papal See recently, but also in its glorious past, during the Constantinian era. It is a way to connect oneself to the memory of the past.

To conclude, archives, whatever their form and modality of operation, were in use in the fourth century and received a strong impulse from Damasus from 366 onwards: 'la notion de scrinium-chartarium ecclesiasticum, ainsi que celle de notarius, présentaient à l'époque tardo-antique des contours bien indécis. Nous savons qu'un certain nombre de tâches documentaires devaient être effectuées: réception, tri, rédaction, compilation, classement; mais les rares indices ne permettent aucune affirmation catégorique ni quant aux effectifs et à la qualité des exécutants', as Dalmon says. ${ }^{61}$

Historiographical writings such as the Chronographer of $354,{ }^{62}$ with the Liberian Catalogue, or the author(s) of Liber pontificalis drew their information from these archives, although we have no idea how they actually worked.

Some very interesting annotations about archival practices also occur in the synodical reports of the Church of Africa. The function of episcopal archives in preserving synodical records is reported more than once, and the merging of different ecclesiastical regional archives is recommended in order to standardise the canonical legislation of the centre (Carthage) with that of the periphery. ${ }^{63}$

60 Martello 2012, 86-88.

61 Dalmon 2015, 150.

62 See Burgess 2013.

63 See the documentation of the Synod of Carthage in the year 525, for example: ed. Munier 1975, 259, 11. 173-179, specifically mention of the matricula (list of contents of the acts) and the archives by the chief bishop of Numidia. See also Munier 1975, 275, 11. 120-123: Bonifatius episcopus dixit: Fiat quod haec congregatio sacerdotum iustissime flagitat. Proferantur ex archiuo huius ecclesiae scripta quae direximus et rescripta quae sumpsimus uel quaecumque ad praesentis negotii pertinent firmitatem. Redemptiolus notarius ex uolumine chartarum recitauit. And concerning a synod held in 402, see Munier 1975, 207, 1l. 845-848: De archiuo et matricula Numidiae. Deinde placuit omnibus episcopis, qui in hoc concilio subscripserunt ut matricula et archiuus Numidiae et apud primam sedem sit et in metropoli, idest Constantina. 


\subsection{Alexandria}

Some ancient information about the staff of the bishopric of Alexandria has been collected by Ewa Wipszycka. ${ }^{64}$ It was concerned in particular with economic matters, but a group of ecclesiastics was tied to the chancery, both as scribes (kankellarios) and as specialists in legal matters (nomikos, a sort of notary, the specialist authorised to write legally binding deeds). In the Life of Severus (sixth century), Bishop Peter Mongus, whose aim was to support the philoponoi's legal action against pagan students, gives them his archidiakonos and primicerius (who is clearly the chief of the notarii). ${ }^{65}$

It is obvious that this activity on the part of the bishop's chancery was reflected in the growth of Alexandrian church archives. Members of the bishop's staff looked after the documents, and it is likely that the bibliophylax attested by Anastasius the Sinaite for the end of the seventh century was in charge of them. ${ }^{66}$ Beyond the documents in the literal sense, the archives preserved texts of a theological nature as well as the acts of synods and canonical literature. We may add to this any documentation of an ecclesiological and political nature, i.e. the correspondence of the bishops with the other colleagues of the Church, with various emperors and state bureaucrats. ${ }^{67}$ In the Coptic History of the Church, notarii are engaged to transcribe Cyril's orations. ${ }^{68}$ Festal letters sent to all the bishoprics of Egypt by clerics were considered important, not only for their religious content and the information they provided on the bishop of Alexandria and the controversies in which he was involved, but also because an appendix to the annual letter contained a list of the new bishops with whom each diocese had to establish communion of faith. ${ }^{69}$ What's more, the documentation connected to the election of each bishop, including the patriarchal letter with which the new bishop came back to his diocese after the consecration in Alexandria, was preserved both in Alexandrian archives and in those of the diocese concerned. ${ }^{70}$ It is from these

\footnotetext{
64 Wipszycka 2015, 237-270, reproducing Wipszycka 2008 with additions.

65 Camplani 2013b, 134.

66 Uthemann (ed.) 1981, 189.

67 See also Cyril of Alexandria's rescript to the Church of Carthago, in Munier 1975, 162, 1l. $16-$ 20: ut de scrinio nostrae ecclesiae uerissima exemplaria ex authentico synodo apud Nicaeam ciuitatem metropolim Bythiniae a sanctis patris constituta atque firmata sub nostrae fidei professione uestrae dilectioni porrigamus. See also the contents of the Codex veronensis LX.

68 Camplani 2013b, 139.

69 The presence of festal letters among the preserved texts in the archives is mentioned in the Life of Aphou, mentioned in Wipszycka 2015, 251 n. 34. See also Camplani 2003, 95-111. 70 Camplani 2003, 53-60; Wipszycka 1996b, 145-50.
} 
kinds of documents that lists of bishops in communion with Alexandria were compiled ${ }^{71}$ giving the information to be used in chronicles and other historiographical writings.

From the style of the Alexandrian chronicles and the documents they mention, we can infer the existence of very rich archives. For example, there are passages in two chronicles composed in Alexandria, the Index to the Festal Letters of Athanasius and the Historia acephala, where it is clear that the compiler or a later scribe had a number of documents at his disposal which he decided to quote or to neglect, whose existence is pointed out to the reader, and is otherwise demonstrated not only by their preservation in manuscripts attesting the works of Athanasius, but also by their being referred to in the Church History of Sozomen and in Coptic fragments of lost works. ${ }^{72}$

Among the documents preserved by the Codex veronensis LX, we find letters that Constantine sent to the Council of Nicaea, his letter against Arius, and documentation concerning the Councils of Nicaea and Serdica: a set of texts which served to promote the Alexandrian see in the Mediterranean world, exalting Alexandria's close relationship with the imperial power and supporting its struggle for primacy vis-à-vis Constantinople. ${ }^{73}$

In other passages we find a detailed account of the movements of presbyters and bishops hour by hour as well as information about new consuls and prefects, which reminds us of the way in which provincial officials reported their own daily activity (commentaria). The attention to buildings, the dedication of churches and natural events, such as the catastrophe of 362/363 mentioned by Ammianus Marcellinus, and other local information which is not found in the standard historiographical works is easily explained by the dependence on ephemerides, ${ }^{74}$ as demonstrated by the following examples extracted from both chronicles:

\footnotetext{
Historia acephala 18. Now in the aforesaid consulship of Lupicinus and Jovinus, Lucius, being specially desirous to claim for himself the episcopate of the Arians a long time after he had left Alexandria, arrived in the aforesaid consulship and entered the town secretly by night on the xxvi day of the month Thoth (24 Sept 367): and as it is said, abode in a certain small house, keeping in hiding for that day. But next day he went to a house where his mother was staying; and his arrival being known at once all over the town, the whole people
}

71 See the lists of bishops preserved in the new Ethiopic historiographical text discussed in Bausi/Camplani 2013 and 2016. For more on Edessa and other dioceses connected to the Syriac Christianity, see Muriel 2015, 365.

72 The existence of the archives of Alexandria is discussed in Martin 1985, 20-21 and 69-73; Camplani 2003, 97-111.

73 Bausi/Camplani 2013, 239-240.

74 Camplani 2003, 87-108. 
assembled and blamed his entry. And Duke Trajanus and the Prefect were extremely displeased at his irrational and bold arrival, and sent officials to cast him out of the town. ${ }^{75}$

Index 39. In this year, when Lucius had attempted an entrance on the twenty-sixth of Thoth and lay concealed by night in a house beside the church where there is the memory of Pieirios; and when Tatianus the Præfect and Trajanus Dux brought him out, he left the city and was rescued in a wonderful manner, while the multitude sought to kill him. ${ }^{76}$

Here we have a detailed narrative, independently drawn by two redactors from the archives of the episcopate, about Lucius and his attempt to conquer the episcopal see of Alexandria. The Alexandrian control devices are so sophisticated that his movements are followed from hour to hour and registered in the ephemerides in the same way in which provincial officers were accustomed in their daily activities.

It is likely that the ephemerides and archival documents were also used by Liberatus of Carthage later, but in an updated form, which probably contained narratives concerning the period after Theophilus as well (d. 412). ${ }^{77}$

\subsection{Antioch}

While the information about the staff of the bishopric of Antioch for the fourth/fifth centuries is less detailed in comparison with that of Alexandria, Annick Martin's analysis of Theodoret's Historia ecclesiastica has suggested the existence of a rich documentation preserved in the archives of the congregations established in Antioch:

La sélection des documents opérée par l'évêque de Cyr pour fonder son point de vue montre qu'il les puise en grande partie dans les archives de l'Église d'Antioche. C'est là en effet qu'il trouve les collections de lettres très tôt regroupées qui ont alimenté la polémique théologique au commencement de la crise ariene, les recueils synodaux constitués à partir d'Euzoios (361-376) et continués sous Mélèce (360-381), contenant Actes et lettres impériales et épiscopales, parfois liés par des parties narratives, à la manière de la Synagôgê de Sabinos utilisée par Philostorge, Socrate et Sozomène - mais non par Théodoret - ou encore de la Collection du diacre Théodose. ${ }^{78}$

75 Martin/Albert 1985, 166-167.

76 Martin/Albert 1985, 200.

77 Ed. Schwartz 1936b. See Blaudeau 2010 on Liberatus. On the relationship between historiography and documents, see Camplani 2015.

78 Martin/Canivet/Bouffartigue/Pietri/Thelamon 2006, 68-69. 
The reconstruction of the contents of the archive has led to some interesting results, which include the following items:

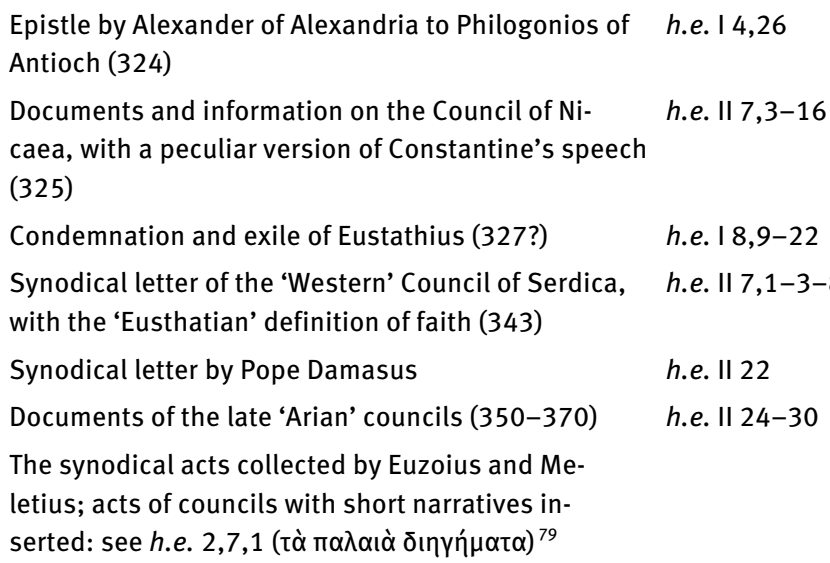

The synodical acts collected by Euzoius and Meletius; acts of councils with short narratives in-

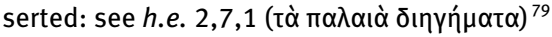

These were some of the archival documents and information used to write an apologetic history of Antioch, such as the one written by Theodoret. The epistolary by Severus of Antioch (512-518), which was penned a hundred years later and has been analysed in a recent book by Frédéric Alpi, ${ }^{80}$ is a good source for reconstructing the situation of both the contents of the Antiochene archives and the activity of their staff. The archeia (bèt-arkē) are explicitly mentioned as well as their personnel:

- the scrinarii (sqrn') for the archives;

- the group of notarii presided over by the scholastikoi; Severus refers to them in his letter to Theotecnus: 'We have [...] sent an ison or copy of the form of satisfaction (plerophoria) which our notaries have drawn up, or having compiled it from other forms (plerophorias) that were previously composed by me in the cases of various persons';

- the few copyists who had the task of producing the copies ('̈oov / isūn) of documents, or checking the style of signatures in the synodical documents to avoid falsified signatures. For instance, in the Letter 1,19 to Solon, bishop of Seleucia in Isauria, Severus discusses the crimes of one Callistus, who was charged with

79 Martin/Canivet/Bouffartigue/Pietri/Thelamon 2006, 57-70.

80 Alpi 2009, I, 83-85. For an edition of Severus' letters, see Brooks 1903-1904 and Brooks 19161920. 
forging a letter that Bishop Hilarian supposedly wrote to Severus. The deception was exposed when 'on comparing the signature of the letter that was produced with the other signatures of the aforesaid God-loving bishop Hilarian that are preserved here in synodal documents, we found them to be as far removed and as different from one another as sheep differ in their appearance from elephants'. Severus continued: '[...] it is clear to everyone that the laws of the Romans, which contain many excellent enactments upon these matters, also fix beheading as the punishment; and this is an offence against public law'.

According to Alpi, Severus' letters attest the richness and varied typology of the texts preserved in the Antiochene archives: synodical epistles (coming from both general and local synods), individual or collective acts of repentance, judgements, books of the Fathers and canon law. Following a suggestion by Honigmann, he assumes that Severus and his staff compiled an anthology of canon law or a Canonicon to support their activity on the basis of the collectio antiochena, which was preserved in the archives and the writings of the Church Fathers. ${ }^{81}$

\section{A case study: Codex veronensis $L X$ as a witness to Alexandrian and Antiochene episcopal archives}

As announced above, in the third part of my contribution to this volume, I intend to offer a number of examples of the method used for recovering lost church archives from two important cities. Such a method consists in (1) looking for claims made by authors, redactors and scribes about their archivia, (2) exploring records of church activities, such as chronicles and histories, which exhibit clear signs of having been drawn from commentaria or collections of documents, and (3) analysing collections presenting similar series of documents (or referring to similar series) and lists of clergy.

The Latin Codex veronensis LX (= Verona Codex) is both an interesting artefact and a collection of documents and narratives preserving traces of a plurality of archives of Late Antique patriarchates. There are clues in the manuscript that allow us to recognise a variety of collections from which it drew its materials,

81 Alpi 2009, 84. 
which in turn come from three different archives: Carthage, Alexandria and Antioch. I have shown elsewhere that in its final appearance it looked like a kind of history of canonical law of the Mediterranean Christian communities, composed with the aim of demonstrating the universality of certain ecclesiastical norms. ${ }^{82}$

Attributed to the seventh to eighth century, the Verona Codex appears to be a composite manuscript. The first 35 leaves are different to the other 90 leaves in terms of their format and page-numbering system. Using Gumbert's terminology, ${ }^{83}$ we can define it as a composite manuscript containing two independent codicological units, which, being written by the same hand, are to be considered 'monogenetic'.

The general content is the canonical legislation of the fourth-century Mediterranean Church, but there are a considerable number of documents concerning events in the fourth and fifth centuries which must be briefly clarified in order to understand the prehistory of some sets of texts: the Arian crisis; the activities of Athanasius of Alexandria, head of the Egyptian Church from 328 to 373; the Council of Serdica (343 CE); the conflicting views of the episcopal sees of Carthage and Rome about the question of the African priest Apiarius, which resulted in a canonical confrontation between the two sees in the years 418-425; the Vandal invasion of Africa in 430 and Vandalic rule until Justinian's reconquest.

- The Arian controversy, which originated in Alexandria around 318/320, soon became a general crisis of the eastern Christian world, also affecting the western part of the empire as well later, in which a long confrontation took place between different episcopal parties, with their own theological traditions and their political ambitions within a Christian state. The Council of Nicaea in 325 failed to result in any solution to the various issues, and the debate went on for decades until the end of the fourth century. ${ }^{84}$

- The figure of Athanasius dominates the fourth-century Church in the Mediterranean world: his anti-Arian positions, his fight against a local schism (originated by Melitius of Lycopolis) and his problematic attitude to the political power, which led him to be exiled five times by Christian emperors, all put him in the centre of eastern Mediterranean Christianity and ecclesiastical documentation from 328 onwards, the year of his election. ${ }^{85}$

82 Camplani 2006a, with a bibliography.

83 Gumbert 2004.

84 See Simonetti 1975, Barnes 1993 and Ayres 2004.

85 See Martin 1996 and Camplani 2003. 
- With the name of the Council of Serdica ${ }^{86}$ we mean an attempt by two emperors, Constant and Constantius, to convene a synod of bishops from the western and eastern part of the empire in 343. The differences in theological and ecclesiastical positions coupled with personal enmity between the attendants caused the failure of this huge meeting of bishops, with the effect that two councils met (the Western and the Eastern), one opposing the other. The synodical acts resulted in two definitions of faith, two sets of conciliar decrees and two sets of reciprocal excommunications. It must be added that while the Eastern Council adopted Greek as the language for its synodical activity, a number of documents issued by the Western bishops were written in Latin and later translated into Greek, so we actually have a double manuscript tradition here as far as Western documentation is concerned.

- As the first part of the codex is connected with the African Church at the beginning of the fifth century, we must refer to a question which is central in the documentation, viz. the 'affair' of Apiarius, a priest of the North African Church, who, condemned by the bishop of his diocese, had appealed to Rome for help. He was consequently reinstated in his post by Pope Zosimus. This intervention was not appreciated in Carthage, but Rome justified it by reference to the canons, which, according to the papal legates, were promulgated by the Council of Nicaea. At this point, Carthage asked other churches to provide the documentation on the Council of Nicaea in order to verify the existence of canons on which Rome based its right to intervene. On the basis of the documentation sent by Alexandria and Constantinople, and perhaps Antioch as well, the African bishops were able to establish and declare that the two canons on which Rome founded its right to intervene in other countries did not actually exist. ${ }^{87}$ Now, we know that although these canons were absent from the Nicene acts, they were not a pure forgery as they are found among the canons of the Western Council of Serdica, a fact of which neither the see of Carthage nor the Eastern patriarchates were aware - or would be aware of after the affair had been concluded either. Were the Roman popes only poor liars? What we know for sure now is that the earliest Roman collection of canons was apparently a document containing the canons of Nicaea and the canons of Serdica as a single combined series under the name of 'Nicaea'. The circumstances of the arrival of these two sets of canons in Rome, as well as of their combination, while generally thought to have been in the mid-fourth century, are unknown. ${ }^{88}$

86 On the synod of Serdica, see Barnard 1983.

87 Pietri 1976, II, 1288-1338.

88 Hess 2002, 56. 
- The Vandalic rule in Africa, which lasted for a century, is only mentioned here to stress the fact that circulation of writings during this period was more difficult than in the preceding and following ones, yet not impossible.

Now we have all the elements we need to come back to the contents of our codex. The first codicological unit contains the proceedings of the Council of Carthage, which, in 419, collected the legislation of the African Church against the claim of Popes Zosimus and Boniface to intervene in cases of ecclesiastical discipline initiated in Africa. The collection also contains the synodical letters sent to Boniface and Celestine later in the name of the African Church. The text of the second letter comes to an abrupt end at the top of the last page, which is blank. It is likely that a page of the exemplar is missing.

In the second codicological unit, in addition to the synodical canons, we find the symbol and canons of the Council of Nicaea, Egyptian and Oriental documents related to the double Council of Serdica of 343, narratives about Athanasius and the Melitian schism, preceding the former's episcopate, accompanied by epistles and other documents.

The hypothesis which can at least partly explain the contents of the two codicological units is that the codex contains documentation on Alexandria and Antioch's responses to the request of the Church of Carthage in 418-419: the two sees sent not only the authentic canons of the Council of Nicaea, but also documents belonging to their archives and proving their authority and importance in the context of Mediterranean Christianity.

Here is a list of the texts according to the traditional numbering:

1 The creed and canons of Nicaea (the so-called Caecilian's version), with a narrative introduction (fols $37 \mathrm{r}-42 \mathrm{v}$ ).

2 The canons of Neocaesarea, in a form of the Isidorian Vulgate (fols $42 v-43 v$ ).

3 A letter addressed by a Roman synod under Damasus in 372 CE to the Eastern bishops, followed by three dogmatic passages by Damasus, followed in turn by a notice of adhesion by Meletius and his synod at Antioch in 379 . The original is stated as being in the Roman archives (fols 43v-47r).

4 The canons of Gangra, in a form of the Isidorian Vulgate (fols $47 \mathrm{r}-50 \mathrm{v}$ ).

5 The canons of Laodicea in the Isidorian version (fols $50 \mathrm{v}-54 \mathrm{v}$ ).

6 The canons of Constantinople in the Isidorian version (fols $54 \mathrm{v}-55 \mathrm{v}$ ).

7 The canons of Ancyra in a form of the Isidorian Vulgate (fols 55v-59r).

8 Part of the Chalcedonian Definitio fidei, with the final allocution of Marcian at the close of the Sixth Session, and the canons (fols 59r-64v).

$8 \mathrm{a}$ The epitome of the canons of Hippo, held in 393 CE (fols 64v-68v).

8 b Ten canons passed by a council of Hippo in 427 CE (fols 68v-70r). 
9 A unique Latin version of the synodical letter of the Council of Nicaea to the churches of Egypt, without the paschal section (fols 70r-71v).

10 Short information about the convocation of the Council of Serdica.

11 The Apostolic canons in the second version of Dionysius Exiguus.

12 The canons of Antioch in the second version of Dionysius Exiguus (fol. 71v + additional leaves).

13 The creed and anathemas of the Eastern bishops at Serdica in a Latin version (fols $78 \mathrm{v}-$ 79v).

14 Another part of the same encyclical, otherwise unknown, proposing a paschal cycle or Easter calendar (fols 79v-80v).

15 The letter from Hosius and Protogenes to Pope Julius retranslated from a Greek version, under the heading Definitiones aput Sardicam (fols 80v-81r).

16 The synodical letter of Western Serdica retranslated from a Greek version, containing the definition of faith known only to Theodoret, h.e. II 8 (fols $81 \mathrm{r}-88 \mathrm{r}$ ).

17 The canons of Western Serdica, retranslated from a Greek version (fols 88r-94v).

18 The canons of Western Serdica in the version of Dionysius Exiguus (in a later hand, written on palimpsest leaves and on two new leaves, fols 97, 98, sewn into the codex for this purpose: fols $94 \mathrm{v}-98 \mathrm{v}$ ).

19 The unique text of an epistle written by Athanasius written from Serdica to the Church of Alexandria (fols 99v-102r).

20 The unique text of an epistle from some bishops at Western Serdica to the Church of the Mareotis (fols 102r-103r).

21 The unique text of a letter written by Athanasius after the synod of Serdica, addressed to the churches of the Mareotis (fols 103r-105r).

22 Vita Athanasii from 345 CE (fols 105r-112r).

23 Under the heading Symbolus sanctae synodi Sardici, a form of baptismal renunciation followed by a Latin confession of faith similar to that of the Council of Constantinople (fol. 112v).

24 A unique Latin version of Constantine's epistle from Nicaea to the Church of Alexandria (fols $112 v-113 v$ ).

25 A unique Latin version of Constantine's 'Porphyrian decree' about Arianism (fol. 113v). ${ }^{89}$

26 Documents connected with the Melitian schism: letter from the four martyrs to Melitius; letter from Peter to the community of Alexandria; short intermediate narrative (fols 113v-116r).

While some portions of the codex appear to retain traces of an archive serving the needs of the episcopate of Alexandria, other sections are connected to Antioch, and in particular to two different and conflicting Christian communities within

89 Note that nos 24-25 have an exclusive parallel in Ethiopic; see Bausi 2006, 62-63 (nos 14-15). 
the city (fourth-fifth centuries). A consideration of the Church History by Theodoret of Cyrrhus and of the documents quoted therein can help us understand the arrangement and precise meaning of some of the sections in the codex.

\subsection{The Alexandrian section}

Some of the historical fragments concerning Alexandria may be identified as belonging to a lost Greek History of the Alexandrian Episcopate (=HEpA, not to be confused with the later Copto-Arabic History of the Patriarchs of Alexandria or the Coptic History of the Church). This work was most likely to have been composed in the last quarter of the fourth century, during the episcopate of Theophilus, but certainly before the activity of Sozomenus the historian, who quoted some passages from it. A section / book of this work is known as Historia Athanasii, which, as we have seen, is a detailed narrative of Athanasius' episcopate; ${ }^{90}$ other sections of the codex which we may attribute to this history are related to the birth and initial development of the Melitian schism under the episcopate of Peter I, to the Nicaean acts and to the Council of Serdica. ${ }^{91}$

Other paraphrases are to be added to the witness of the Verona Codex which have been recognised by scholars in later historiographical and hagiographical sources; the most important witness is now the historical text that Alessandro Bausi has identified in an Ethiopic collection. ${ }^{92}$

On the one hand, the Verona Codex is one of the hundreds of late antique codices preserving canonical writings, such as conciliar decrees and canons, liturgical writings, official letters, from the East and the West: the codex and the compilations upon which it is based responded, as many other codices did, to the 'constantly evolving need of the Church to collect and transmit authoritative precedents by which it could govern its own affairs'.$^{93}$ On the other hand, the Verona Codex is marked by some codicological peculiarities and characterised by rare texts-features that require a correct methodology of investigation.

The fact that it contains rare texts also preserved in the Ethiopic manuscript described by Alessandro Bausi gives us reason to insist on the notion and historical reality of episcopal archives. We have to take a fact into consideration which could be useful for our investigation, whose aim is to reconstruct lost archives

90 Martin/Albert 1985, 138-213.

91 For editions of the texts, see inter alia Turner 1939, Brennecke/Heil/von Stockhausen/ Wintjes 2007; Field 2004; Martin 1985.

92 See Bausi 2002; Bausi 2006; Bausi/Camplani 2013.

93 Field 2004, 115. 
through the traces they have left in canonical and historical compilations: an archive is something that evolves over the course of time, so documents could have been added to it as soon as they were written or as soon as they were received from other sees; in other words, an archive can assume different states according to the chronology and the historical context. It is important for us to understand which state of an archive a single codex or a single set of texts is a selection of.

The authors of the HEpA selected all the items in the bishopric's archives which could support the ecclesiological and political primacy of the See of Alexandria in the eastern Mediterranean and its jurisdiction over Egypt and Libya: letters from the emperors, synodical acts, documents from the bishop-martyrs attempting to prevent ecclesiastical schisms, list of bishops appointed by the patriarchs, and suchlike. ${ }^{94}$

\subsection{The Antiochene section}

While some portions of the Verona Codex, as we have seen, retain items of an archive serving the needs of the episcopate of Alexandria, other sections should be connected not only to Antioch, but also to a specific phase of the Antiochene episcopate, from the last quarter of the fourth century to the first quarter of the fifth. ${ }^{95}$ This sub-collection of texts, ${ }^{96}$ partially attested by a group of Syriac codices as well-Paris Bibliothèque nationale de France syr. $62^{97}$ and others ${ }^{98}$-and, above all, alluded to by Theodoret of Cyrrhus, h.e. II, preserves documents with different ideological orientations side by side, which were produced on the occasion of the synod of Serdica (343) by two different groups of bishops who, in all likelihood, put them in two different archives immediately after the dramatic end of the Council's meeting. However, the fact that these contradictory documents are witnessed together by such different witnesses (a Latin collection, some Syriac canonical codices and a historian) can only be explained by arguing that they were put together in a single Greek archive at some point in history, from which

94 See Camplani 2004, 2006a, 2009a, 2011, 2013b, 2015.

95 On the Antiochene canonical collections, see Mardirossian 2010; regarding their origin, see Schwartz 1936c.

96 See Schwartz 1936a, Telfer 1943, Field 2004. A complete edition of the texts discussed in the present paper is in Turner 1939.

97 The documents which are discussed here were published on the basis of Paris syr. 62 by Schulthess 1908.

98 These are Mardin, Library of the Residence of the Archbishopric 309, 310, 320 (modern copy), Vat. Borg. syr. 148 (1576 CE). See Camplani 2013a. 
they were then drawn and subsequently translated into different languages. What are the historical circumstances that produced this strange juxtaposition of documents?

As anticipated, we should pay attention to the following items:

10 Short notice about the convocation of the Council of Serdica.

13 The creed and anathemas of the Eastern bishops at Serdica.

14 A paschal cycle or Easter calendar.

15 The letter from Hosius and Protogenes to Pope Julius retranslated from a Greek version.

16 The synodical letter of Western Serdica retranslated from a Greek version, containing the definition of faith known only to Theodoret (h.e. II 7,1-3-8,1-53).

17 The canons of Western Serdica, retranslated from a Greek version.

19 The unique text of an epistle written by Athanasius from Serdica to the Church of Alexandria.

20 The unique text of an epistle from some bishops at Western Serdica to the Churches of the Mareotis.

21 The unique text of a letter written by Athanasius after the synod of Serdica, addressed to the Churches of the Mareotis.

What needs a more critical appreciation is the fact that the symbol of the Eastern Council, accompanied by the paschal cycle (nos 13-14), whose provenance from Antioch should not be doubted, as demonstrated by Telfer, ${ }^{99}$ presents some interpolations transforming its theological language in agreement with that of the Council of Nicaea. It is as if someone, noticing some oddities in the Trinitarian orientation of the document, adapted it as closely as possible to the terminology which he regarded as 'orthodox'. This could only happen with the decline of the Arian community of Antioch around 378. This phenomenon is not unique in Codex Veronensis LX (58). The Syriac translation of the same document preserved in the codex Paris. syr. 62, fols 182-183, also shows the same interpolations. ${ }^{100}$ It is possible to argue that the text of the council of the Eastern section of the Council of Serdica has been intentionally interpolated by those who were organising the archives of Antioch when the acute phase of the Arian controversy was drawing to an end (and therefore under the bishopric of Meletius, 360-381 CE), and when the need was felt to adapt the language to that of the pro-Nicene bishops of the Western part of the empire.

99 Telfer 1943.

100 Schulthess 1908, 167-168; Camplani 2013a. 
Moreover, while the texts concerning Egypt and Athanasius may have been drawn from Alexandrian archives (nos 19-21), as evidenced by their local character, the three most important documents of the council, namely Julius' letter to Protogenes, the synodical letter of the Western section of the Synod and the famous conservative definition of faith (nos 15-17), all translated into Latin from an unknown Greek version, are unlikely to have come from this city. The synodical letter is apparently a Latin version of a Greek model that is different from the one recorded in the works of Athanasius of Alexandria (Apologia secunda contra arianos, 37-41). The definition of faith that follows is exactly the same one that Athanasius, from 362 onwards (Tomus ad Antiochenos), tried to obliterate, because its radical pro-Nicene tendency was an obstacle to his attempts to approach the party of Meletius of Antioch. More caution is required regarding the two other documents in this small series (15 and 17), but the very fact that the set constitutes a series in itself makes their Alexandrian origin unlikely.

We are therefore in search of another place of production and preservation for this little collection. Several scenarios have already been proposed. According to the first reconstruction, these documents were transmitted to Alexandria directly from Serdica and then from there to Carthage (this also happened before the beginning of the Apiarian affair). However, as I have noted, it seems unlikely that they passed through Alexandria. According to a second scenario, they were taken to Africa and Rome at the end of the Vandal domination and in connection with the circulation of the eastern canonical collections, that is to say, in the second half of the sixth century. Thessalonica and other cities have been proposed in addition as places from which these documents moved to Carthage. ${ }^{101}$

Since there are serious objections to each of these reconstructions, a new hypothesis is called for. In my view, following Annick Martin's analysis of Theodoret's history, there is only one community in which the definition of faith (no. 16) could be preserved together with the West Serdican documentation: the community of the Eustathians of Antioch, i.e. the congregation directed by Pauline, leader of the conservative Nicene group. ${ }^{102}$

Theodoret, as we know, drew his documentation from the archives in Antioch. From an ideological and ecclesiological point of view, he belonged to the group that was heir to Meletius, Diodorus of Tarsus and John Chrysostom, i.e. the rival group to the Eustathian Paulinus. However, in his historiographical activity, he oddly put two figures side by side that he considered the foundations of Antiochene orthodoxy, viz. Eustathius, exiled by the Arians, and Meletius, himself

101 See Telfer 1943.

102 Martin/Canivet/Bouffartigue/Pietri/Thelamon 2006-2009, 68-92. 
persecuted by the emperors for his moderately anti-Arian position, but originally appointed by groups of bishops close to the Arian movement, at least according to his opponents. ${ }^{103}$ We know that the historical reality is different from Theodoret's harmonising representation: gathered around the two figures there were two different and opposing communities, viz. the group heir to Eustathius, led by Paulinus, a bishop of Antioch irregulary ordained by Lucifer of Calaris around 360, and recognised as bishop by the West (Damasus, Ambrose), and Meletius, on the other side, who was not only followed by a group of believers who were moderately anti-Arian and pro-Nicene (neo-Nicene), but also attracted most of the bishops of Syria to his side. For a long time, despite the ideological proximity, there were many obstacles to the dialogue between the two communities living in the same city.

What is most striking in Theodoret's history is his quotation of the documentation related to the Eustathians led by Paulinus, who were distant from his line of thought. In fact, this group was in possession of documents issued by the Western bishops who had met in Serdica, including the definition of faith that Athanasius dismissed because its strict Nicene language was too radical.

If Theodoret speaks about Meletians and Eustathians as orthodox groups, and if he quotes documents coming from the Western section of the Council of Serdica, notoriously far from his party, it is not surprising to find the Eastern (interpolated) and Western definitions of faith next to each other in the Verona Codex. Both Theodoret and the editors of the collections copied in the Verona Codex thus drew their material from a new archive created by merging two older archives owned by two rival groups. In what historical circumstances did this happen? In the early fifth century, some attempts were made to bring about peace between the two opposing congregations. Under Bishop Alexander they came into communion, as attested by Theodoret, h.e. V 37:

By his [i.e. Bishop Alexander's] advice and exhortation, the following of the great Eustathius which Paulinus, and after him Evagrius, had not permitted to be restored, was united to the rest of the body, and a festival was celebrated, the like of which none had ever seen before. The bishop gathered all the faithful together, both clergy and laity, and marched to the assembly with them. The procession was accompanied by musicians; one hymn was sung by all in harmony, and thus he and his company went in procession from the western postern to the great church, filling the whole forum with people and constituting a stream of thinking living beings like the Orontes in its course.

103 Martin 2009, 281-287. 
In other words, Theodoret and the Verona Codex attest to the same historical climate, which, in the early fifth century, bringing peace between the communities of Antioch, resulted in the merging of their archives.

At this point, we can say we have solved the mystery of the origin of texts 1314 and 15-17 of the Verona Codex: these texts are ultimately attributable to the Antiochene archive gathering the textual heritage of both Eustathius and Meletius after the beginning of the fifth century. That means giving an answer to the question about the fate of the material required by Carthage from the Antiochene church in the context of the question of Apiarius, which some scholars considered definitively lost.

\subsection{Between Antioch's and Rome's episcopal archives: the Exemplum synodi}

Another peculiar document in the Verona Codex (text no. 3: fols 43v-47r) comes from the same context. ${ }^{104}$ It is worth mentioning because of its complicated prehistory, which left textual traces in the codex. It is introduced by the rubric 'Exemplar of the Synod of 93 Bishops Held in Rome: From the Imperial Rescript', ${ }^{105}$ which connects the contents of the composite document issued by a synod to an imperial decree. The document consists of a letter addressed by a Roman synod under Damasus (in 371?) to the Catholic bishops of the Orient (also known to Theodoret, h.e. II 22), authenticated by a deacon from Milan called Sabinus, who was renowned for his diplomatic activity in the East around 372 ('I, Sabinus, deacon of Milan, have authenticated (this) (de authentico dedi) as legate'106), followed by three dogmatic passages culled from letters written on the Roman side of the controversy with the Orientals presented as a decree (the formula item ex parte decreti, 'also from part of the decree', occurs three times before each quotation), followed again by a note which declares that Meletius and his synod, convened at Antioch in 379, adhered to these excerpts:

104 See the edition and rich commentary in Field 2004.

105 Exemplum synodi habitae Romae episcoporum XCIII ex rescripto imperiali.

106 Ego Sabinus diaconus mediolanensis legatus de authentico dedi. 
This exposition or letter from the Roman synod held under Pope Damasus was also transmitted to the East, in which a synod was made at Antioch with every Eastern church in harmony with the faith. That all believe, and thus consent to, the same faith expounded above, each individual confirmed by his own signature. ${ }^{107}$

After a certain number of signatures, we read the following information:

\begin{abstract}
Similarly, the other 146 Eastern bishops all signed their names under it. Their signatures are [still visible] on the original document, which is kept in the archives of the Roman Church. ${ }^{108}$
\end{abstract}

Thus, we have a composite document at our disposal which is connected to more than one archive, has been subject to authentication in an ecclesiastical chancery and became part of an imperial decree enforcing it-a very rare kind of document indeed. The form in which it appears in the codex is the result of a series of interventions and transformations which the paratextual elements already mentioned above help us detect:

- the letter Confidimus quidem, which is the synodical letter of a Roman synod (under Damasus);

- the authentication of it by Sabinus the legate, which occurred in a chancery or archive that probably differed from the Roman one (see below);

- the word decretum, which refers to each of the three following Roman pieces, as if the whole thing should be considered the act of another (Roman?) synod, convened later than that of Confidimus quidem;

- the notice of adhesion by Meletius and his synod;

- the fact that the whole document is taken ex rescripto imperiali;

- finally, the location of the authentic copy of the whole document.

This text has been studied by Schwartz, but it is the recent penetrating analysis by Field which allows us to understand the whole document and its elements now, including the paratextual sentences it contains.

From Thedoret (h.e. II 22) and from other historians, ${ }^{109}$ we know that around 371 a Roman synod sent a letter to the Illyrian bishops, whose Greek text is parallel to Confidimus quidem. In Codex veronensis LX, the latter is said to have been

107 Haec expositio uel epistola synodi romanae habitae sub Damaso Papa et transmissa ad Orientem in qua omnis Orientalis ecclesia facta synodo aput Antiochiam consona fide credentes et omnes ita consentientes eidem super expositae fidei singuli sua subscriptione confirmant.

108 Similiter et alii CXLVI Orientales episcopi subscripserunt, quorum subscriptio in authenticum hodie in archiuis romanae ecclesiae tenetur.

109 Field 2004, 117. 
addressed to Eastern bishops-two pieces of information that are not necessarily contradictory, since the same synod could write the same letter, or two similar letters, to different groups of bishops. As for the exact date of this first historical event, we have to consider the mention of the condemnation of Auxentius, the bishop of Milan, who is presented as still alive: his death must have been before 374, so the synod could be dated between 368 and 374. In the second of the three subsequent excerpts, a presbyter called Dorotheus is mentioned, one of Meletius of Antioch's assistants in his difficult relationship with Western Christianity and with Athanasius; he became a presbyter between 372 and 376. ${ }^{110}$ From other sources, we know that Meletius called a synod in 372 stressing the orthodoxy shared with the Nicene West; then, a persecution of the Nicene bishops in the East lasted from 373 to 378, limiting the opportunities to convene synods. After that date, things got easier and Meletius was able to convene a synod to assent to the Roman synodical letters.

Given this historical context, we need to take the following facts into consideration:

1) the authentication made by Sabinus in relation to the first part of the text, the synodical letter of the council under Damasus (Confidimus quidem, 372?), makes no sense if referred to the Roman archives, explicitly mentioned in the final note: this authentication was probably a way of identifying Confidimus quidem in the Antiochene archives after it was received from Rome, at a time when Antioch was being visited by Sabinus the deacon; ${ }^{11}$

2) the last part of the document was the result of an Antiochene synod held in 379 by Meletius and other Eastern bishops;

3) the other items of Roman provenance could have been added to Confidimus quidem or in Rome, or in Antioch, or by the author of the imperial decree;

4) the imperial rescript carrying the synodical letter, which could only be sent out after Auxentius' death in 374 (an 'Arian' bishop who was recognised by the emperor) and before 381, marks the imperial involvement in the pacification of the Eastern churches and in the Antiochene controversy; this imperial decree was probably composed on the base of pieces coming from the Antiochene archives, rather than the Roman ones;

5) the mention of the Roman archives is interesting, but difficult to date. Is it the work of a first Antiochene redactor collecting the Antiochene and Roman material before it was sent to Carthage, together with other pieces of Antiochene history,

110 Field 2004, 119, n. 7.

111 Field 2004, 133. 
as a contribution to the Apiarian case (419)? Is it a note by a later redactor who assembled Alexandrian and Antiochene materials in Carthage or other places, precisely the one who is responsible for eliminating things he considered superfluous here and there (fifth-sixth century)? Or is it a declaration made by the scribe who wrote down the codex (in the seventh-eighth century)?

If the first hypothesis could be argued in some way, this mention would be one of the very first attestations to the existence of a papal archive and its way of working around 370-380 CE.

\section{Provisional conclusions}

The partial preservation of a limited number of Christian episcopal archives from Late Antiquity has directed our research towards other kinds of sources, which give us the opportunity to reveal archival activity and archival discourse in Christian congregations. These were ecclesiastical histories, in particular those by Eusebius, Theodoret and Sozomenus, as well as the episcopal histories which we can recover from miscellaneous manuscripts preserving canonical literature. The results of our enquiry may be summarised with the following statements:

a) Christianity was born and grew in a society in which archives not only were a reality of everyday life, but had very high recognition in the public eye. Before creating their own archives, Christian congregations adhered to the archival discourse of their times, and the mention of archives in the writings of their intellectuals served apologetic and theological aims;

b) it was with the birth of the bishop as a leading figure in Christian congregations that the necessity of archives was felt. Not only did the diverse activities of a leader on whom religious, educational, cultic and practical functions converged need archival activities, but the meetings of bishops (synods) also produced a very large amount of documentation and were based on just as much documentation of the past, for the consultation of which archives were essential. The new archives were a reflection of a congregational structure that was becoming more and more articulated and complex and, at the same time, dominated by an increasingly autocratic leadership. The arrangement of these archives imitated the functioning of public or private archives while adapting their features to the specific purposes of social and religious character typical of Christian congregations. 


\section{References}

Adler, William (2012), 'Christians and the Public Archive', in Eric F. Mason (ed.), Teacher for All Generations. Essays in Honor of James C. VanderKam (Supplements to the Journal for the Study of Judaism 153), Leiden, New York, Cologne: Brill, 917-937.

Adler, William (2013), 'The Kingdom of Edessa and the Creation of a Christian Aristocracy', in Natalie B. Dohrmann and Annette Yoshiko Reed (eds), Jews, Christians, and the Roman Empire: The Poetics of Power in Late Antiquity, Philadelphia: University of Pennsylvania Press, 43-62, 277-282.

Alpi, Frédéric (2009), La route royale. Sévère d'Antioche et les églises d'Orient (512-518), 2 vols (Bibliothèque archéologique et historique, 188), Beyrouth : Presses de l'Ifpo.

Ayres, Lewis (2004), Nicaea and its Legacy: An Approach to Fourth-Century Trinitarian Theology, Oxford: Oxford University Press.

Bagnall, Roger (2009), Early Christian Books in Egypt, Princeton, NJ: Princeton University Press. Barnard, Leslie W. (1983), The Council of Serdica 343 A.D., Sofia: Synodal Pub. House.

Barnes, Timothy D. (1993), Athanasius and Constantius. Theology and Politics in the Constantinian Empire, Cambridge, MA, London: Harvard University Press.

Bausi, Alessandro (2002), 'New Egyptian Texts in Ethiopia', in Adamantius, 8, 146-151.

Bausi, Alessandro (2006), 'La Collezione aksumita canonico-liturgica', in Adamantius, 12, 43-70.

Bausi, Alessandro, and Alberto Camplani (2013), 'New Ethiopic Documents for the History of Christian Egypt', in Zeitschrift für Antikes Christentum - Journal of Ancient Christianity, 17, 215-247.

Bausi, Alessandro, and Alberto Camplani (2016), 'The History of the Episcopate of Alexandria (HEpA): Editio minor of the fragments preserved in the Aksumite Collection and in the Codex Veronensis LX (58)', in Adamantius, 22, 249-302.

Bernardini, Paolo (2009), Un solo battesimo, una sola chiesa. Il concilio di Cartagine del settembre 256 (Testi e ricerche di scienze religiose. Nuova serie 43), Bologna: Il Mulino.

Blaudeau, Philippe (2010), 'Liberatus de Carthage ou l'historiographie comme service diaconal', in Augustinianum, 50, 543-566.

Blumell, Lincoln H., and Thomas A. Wayment (2015), Christian Oxyrhynchus. Texts, Documents, and Sources, Waco, Texas: Baylor University Press.

Brennecke, Hanns C., Uta Heil, Annette von Stockhausen, and Angelika Wintjes (eds) (2007), Athanasius Werke. III/1: Dokumente zur Geschichte des arianischen Streites, 3: Bis zur Ekthesis makrostichos, Berlin, New York: De Gruyter.

Brock, Sebastian P. (1992-1999), 'Eusebius and Syriac Christianity’, in Harold W. Attridge and Gōhei Hata (eds), Eusebius, Christianity, and Judaism, Leiden, New York, Cologne: Brill 1992, 212-234; republished in Sebastian P. Brock, From Ephrem to Romanos. Interactions between Syriac and Greek in Late Antiquity (Variorum Collected Studies Series CS644), Aldershot, Brookfield, Singapore, Sydney: Routledge 1999 (no. 2).

Brooks, Ernest W. (1903-1904), The Sixth Book of the Select Letters of Severus, Patriarch of Antioch, in the Syriac Version of Athanasius of Nisibis, II: Pt. I, Pt II, London: Williams \& Norgate.

Brooks, Ernest W. (1916-1920), A Collection of Letters of Severus of Antioch from numerous Syriac manuscripts (Patrologia orientalis, 12, 14), Paris: Firmin-Didot.

Burgess, Richard W. (2013), 'The Chronograph of 354: Its Manuscripts, Contents, and History', in Journal of Late Antiquity, 5, 345-396. 
Burgess, Richard W., and Michael Kulikowski (2013), Mosaics of Time. The Latin Chronicle Traditions from the First Century $B C$ to the Sixth Century $A D$, Volume I: A Historical Introduction to the Chronicle Genre from its Origins to the High Middle Ages (Studies in the Early Middle Ages, 33), Turnhout: Brepols.

Camplani, Alberto (2003), Atanasio di Alessandria: Lettere festali. Anonimo: Indice delle lettere festali (Letture cristiane per il primo millennnio, 34), Milano: Paoline.

Camplani, Alberto (2004), 'L'autorappresentazione dell'episcopato di Alessandria tra IV e V secolo: questioni di metodo', in Annali di storia dell'esegesi, 21, 147-185.

Camplani, Alberto (2006a), 'Lettere episcopali, storiografia patriarcale e letteratura canonica: a proposito del Codex veronensis LX (58)', in Rivista di storia del cristianesimo, 3, 117164.

Camplani, Alberto (2006b), 'Le trasformazioni del cristianesimo orientale: monoepiscopato e sinodi (II-IV secolo)', in Annali di storia dell'esegesi, 23, 67-114.

Camplani, Alberto (2009a), 'Pietro di Alessandria tra documentazione d'archivio e agiografia popolare', in Heike Grieser and Andreas Merkt (eds), Volksglaube im antiken Christentum. Prof. Dr. Theofried Baumeister OFM zur Emeritierung, Darmstadt: Wissenschaftliche Buchgesellschaft, 138-156.

Camplani, Alberto (2009b), 'Traditions of Christian Foundation in Edessa. Between Myth and History', in Studi e Materiali di Storia delle Religioni 75 (= Alberto Camplani, Giulia Piccaluga and Alessandro Saggioro (eds), Città pagana - città cristiana. Tradizioni di fondazione. Atti del convegno di Roma, 2-3 luglio 2007), 251-278.

Camplani, Alberto (2011), 'A Syriac fragment from the Liber historiarum by Timothy Aelurus (CPG 5486), the Coptic Church History, and the archives of the bishopric of Alexandria', in Paola Buzi and Alberto Camplani (eds), Christianity in Egypt: Literary Production and Intellectual Trends. Studies in Honor of Tito Orlandi (Studia Ephemeridis Augustinianum, 125), Rome: Istituto Patristico Augustinianum, 205-226.

Camplani, Alberto (2012), 'A Pastoral Epistle of the Seventh Century Concerning the Eucharist (Pap. Berlin P. 11346)', in Verena M. Lepper (ed.), Forschung in der Papyrussammlung. Eine Festgabe für das Neue Museum (Für das Ägyptische Museum und Papyrussammlung Staatliche Museen zu Berlin, Ägyptische und Orientalische Papyri und Handschriften des Ägyptischen Museums und Papyrussammlung Berlin Band 1), Berlin: Akademie Verlag, 377-386.

Camplani, Alberto (2013a), 'Fourth-Century Synods in Latin and Syriac Canonical Collections and their Preservation in the Antiochene Archives (Serdica 343 CE - Antioch 325 CE)', in Sofia Torallas Tovar and Juan Pedro Monferrer-Sala (eds), Cultures in Contact. Transfer of Knowledge in the Mediterranean Context (Series Syro-Arabica, 1), Cordoba, Beyrouth: Oriens Academic, 61-72.

Camplani, Alberto (2013b), 'The Transmission of Early Christian Memories in Late Antiquity: The Editorial Activity of Laymen and Philoponoi', in Brouria Bitton-Ashkelony and Lorenzo Perrone (eds), Between Personal and Institutional Religion. Self, Doctrine, and Practice in Late Antique Eastern Christianity, Turnhout: Brepols,129-154.

Camplani, Alberto (2015), 'The religious identity of Alexandria in some ecclesiastical histories of Late Antique Egypt', in Philippe Blaudeau and Peter van Nuffelen (eds), L'historiographie tardo-antique et la transmission des savoirs (Millennium-Studien zu Kultur und Geschichte des ersten Jahrtausends n. Chr. 55), Berlin, Munich, Boston: De Gruyter, 85119.

Crum, Walter E. (1902), Coptic Ostraca from the Collections of the Egypt Exploration Fund, the Cairo Museum and others, London: The Egypt Exploration Fund. 
Dalmon, Laurence (2015), Un dossier de l'Épistolaire augustinien: la correspondance entre l'Afrique et Rome à propos de l'affaire pélagienne (416-418): traduction, commentaire et annotations (Studia patristica Supplement, 3), Leuven: Peeters.

Dekker, Renate (2011), 'Reconstructing and re-editing the archive of bishop Pesynthios', in Maarten Horn et al. (eds), Current Research in Egyptology 2010, Oxford: Oxbow Books, 33-41.

Debié, Muriel (2015), L'écriture de l'histoire en syriaque. Transmissions interculturelles et constructions identitaires entre hellénisme et islam. Avec des répertoires des textes historiographiques en annexe (Late Antique History and Religion, 12), Louvain: Peeters

Desreumaux, Alain (1993), Histoire du roi Abgar et de Jésus, Présentation et traduction du texte syriaque intégral de la Doctrine d'Addaï (Apocryphes: Collection de poche de l'AELAC), Paris, Turnhout: Brepols.

Duchesne, Louis (ed.) (1886-1892), Le Liber Pontificalis. Texte, introduction et commentaire, Paris: Ernest Thorin (see Le Liber pontificalis, I, Anastatic reimpression of the first edition with a preface by Jean Bayet, Bibliothèque des Écoles françaises d'Athènes et de Rome, 2e série, Registres et lettres des papes du XIIIe siècle, III, 1-3, Paris 1955).

Duval, Yvette (2000), Chrétiens d'Afrique à l'aube de la paix constantinienne. Les premiers échos de la grande persécution (Collection des Études Augustiniennes, 164), Paris: Institut d'Études Augustiniennes.

Fiaccadori, Gianfranco (2014), 'Archives and libraries', in Encyclopaedia Aethiopica, V: Y-Z. Supplementa, Addenda et Corrigenda, Maps, Index, Wiesbaden: Harrassowitz, 244-248.

Field, Lester L. (2004), On the Communion of Damasus and Meletius: Fourth-Century Synodal Formulae in the Codex Veronensis LX (Studies and Texts, 145), Toronto: Pontifical Institute of Medieval Studies.

Francia, Rita (2015), 'Archivi e biblioteche a Hattuša: alcune riflessioni', in Elena Asero (ed.), Strade di uomini e di idee. La circolazione materiale e interculturale tra mediterraneo orientale e vicino Oriente antico. Atti del convegno (Milano, 8-9 luglio 2013), Rome: Aracne, 33-44.

Friedrich, Markus (2013), Die Geburt des Archivs. Eine Wissensgeschichte, Munich: Oldenbourg.

Gamble, Harry Y. (1995), Books and Readers in the Early Church. A History of Early Christian Texts, New Haven, London: Yale University Press.

Gaudemet, Jean (1958), L'Église dans l'Empire romain (IVe-Ve siècles), Paris: Sirey.

Gaudemet, Jean (1994), Église et cité: histoire du droit canonique, Paris: Cerf.

Giorda, Maria Chiara (2007), 'Una rassegna di fonti documentarie per lo studio del monachesimo egiziano', in Adamantius, 13, 379-393.

Guidi, Ignazio (1903), Chronica minora. Pars prior (Corpus Scriptorum Christianorum Orientalium, Scriptores Syri, Series III, Tomus IV), Paris: E Typ. Reipublicae.

Gumbert, Johan P. (2004), 'Codicological units: Towards a Terminology for the Stratigraphy of the Non-Homogeneous Codex', in Segno e Testo, 2, 17-42.

Hess, Hamilton (2002), The Early Development of Canon Law and the Council of Serdica, 0xford: Oxford University Press.

Howard, George (transl.) (1981), The Teaching of Addai (Society of Biblical Literature Texts and Translations, 16, Early Christian Literature Series, 4), Chico, CA: Scholars Press.

Krause, Martin (1956), Apa Abraham von Hermonthis. Ein oberägyptischer Bischof um 600, 2 vols, Dissertation, Berlin. 
Krause, Martin (1991a), Abraham of Hermonthis, in Aziz S. Atiya (ed.), The Coptic Encyclopedia, New York: Macmillan, 13a-b.

Krause, Martin (1991b), Archives, in Aziz S. Atiya (ed.), The Coptic Encyclopedia, New York: Macmillan, 226a-228a.

Lake, Kirsopp (transl.) (1926), Eusebius. Ecclesiastical History, I (Loeb Classical Library), London, New York: Harvard University Press.

Luijendijk, AnneMarie (2008), Greetings in the Lord: Early Christians in the Oxyrhynchus Papyri (Harvard Theological Studies, 60), Cambridge: Harvard University Press.

Mardirossian, Aram (2010), La Collection canonique d'Antioche. Droit et hérésie à travers le premier recueil de législation ecclésiastique (IVe siècle) (Centre de recherche d'histoire et civilisation de Byzance. Monographie, 34), Paris: Collège de France.

Martello, Fabrizio (2012), All'ombra di Gregorio Magno. Il notaio Paterio e il Liber testimoniorum, Rome: Città Nuova.

Martin, Annick, and Micheline Albert (eds) (1985), Histoire «acéphale» et index syriaque des lettres festales d'Athanase d'Alexandrie (Sources chrétiennes, 317), Paris: Cerf.

Martin, Annick (1985), 'Introduction', in Martin/Albert 1985, 11-67.

Martin, Annick (1996), Athanase d'Alexandrie et l'Église d'Égypte au IVe siècle (328-373) (Collection de l'École française de Rome, 216), Rome: École française de Rome.

Martin, Annick, Pierre Canivet, Jean Bouffartigue, Luce Pietri and François Thelamon (eds) (2006-2009), Théodoret de Cyr, Histoire ecclésiastique (Sources chrétiennes, 501, 530), Paris: Les Éditions du Cerf.

Martin, Annick (2009), 'Antioche aux IVe et Ve siècles. Un exemple de réécriture orthodoxe de l'histoire chrétienne', in Studi e materiali di storia delle religioni 75 (= Alberto Camplani, Giulia Piccaluga and Alessandro Saggioro (eds), Città pagana - città cristiana. Tradizioni di fondazione. Atti del convegno di Roma, 2-3 luglio 2007), 279-294.

Mathisen, Ralph W. (1998), 'Et manu papae: Papal Subscriptions Written sua manu in Late Antiquity', in Gareth Schmeling and Jon D. Mikalson (eds), Qui miscuit utile dulci. Festschrift Essays for Paul Lachlan MacKendrick, Wauconda: Bolchazy-Carducci Publishers, 243-251.

Montanari, Giovanni (1992), 'Culto e liturgia a Ravenna dal IV al IX secolo', in Antonio Carile (ed.), Storia di Ravenna, II/2: Dall'età bizantina all'età ottoniana. Ecclesiologia, cultura e arte, Venice: Comune di Ravenna and Marsilio.

Moreau, Dominic (2010), 'Non impar conciliorum extat auctoritas. L'origine de l'introduction des lettres pontificales dans le droit canonique', in Janine Desmulliez, Christine Hoët-van Cauwenberghe and Jean-Christophe Jolivet (eds), L'étude des correspondances dans le monde romain de l'Antiquité classique à l'Antiquité tardive: permanences et mutations. Actes du XXX Colloque international de Lille (Lille, 20-22 novembre 2008) (UL3: Travaux \& recherches), Lille: Presses de l'Université Charles-de-Gaulle - Lille, 487-506.

Moreau, Dominic (2012a), De rebus exterioribus. Recherches sur l'action temporelle des évêques romains, de Léon le Grand à Grégoire le Grand (440-604 ap. J.-C.). Sources et approches; Les actes pontificaux comme sources des historiens, Thèse pour obtenir le grade de Docteur de l'Université Paris-Sorbonne, Paris.

Moreau, Dominic (2012b), 'Deux notes sur l'utilisation du terme rege(/i)st(r)um pour désigner les recueils d'actes pontificaux antiques', in Stéphane Gioanni and Paolo Cammarosano (eds), La corrispondenza in Italia - Les correspondances en Italie, II: Forme, stili e funzioni della scrittura epistolare nelle cancellerie italiane (secoli $V-X V$ ) - Formes, styles et fonctions de l'écriture épistolaire dans les chancelleries italiennes (Ve-XVe siècle) (Atti 6 / Collection de l’École française de Rome, 475), Trieste, Rome: École française de Rome, 73-91. 
Moreau, Dominic (2015), 'Les actes pontificaux comme sources des historiens et des chroniqueurs de l'Antiquité tardive', in Philippe Blaudeau and Peter van Nuffelen (eds), L'historiographie tardo-antique et la transmission des savoirs (Millennium-Studien zu Kultur und Geschichte des ersten Jahrtausends n. Chr. 55), Berlin, Munich, Boston: De Gruyter, 23-53.

Munier, Charles (ed.) (1974), Concilia Africae A. 345 - A. 525 (Corpus Christianorum, Series Latina, 149), Turnhout: Brepols.

Norelli, Enrico (2001), 'Ignazio di Antiochia combatte veramente dei cristiani giudaizzanti?', in Giovanni Filoramo and Claudio Gianotto (eds), Verus Israel. Nuove prospettive sul giudeocristianesimo. Atti del Colloquio di Torino (4-5 novembre 1999), Brescia: Paideia, 220264.

Norelli, Enrico (2006), 'Scrivere per governare. Modi della comunicazione e rapporti di potere nel cristianesimo antico. Introduzione al convegno', in Rivista di storia del cristianesimo, 3, 5-30.

Norelli, Enrico (2012), 'Una pluralità limitata. Il rovesciamento di paradigma nel II secolo come base della formazione del canone neotestamentaria', in Antonio Autiero and Marinella Perroni (eds), La Bibbia nella storia d'Europa: dalle divisioni all'incontro, Bologna: Edizioni Dehoniane Bologna, 47-92.

Opitz, Hans-Georg, Hanns Christof Brennecke, Uta Heil and Annette von Stockhausen (eds) (1935-2006), Athanasius Werke, II/1: Die Apologien, Berlin, Leipzig, New York: De Gruyter.

Phillips, George (1876), The Doctrine of Addai, the Apostle, Now First Edited in a Complete Form in the Original Syriac, London: Trübner.

Pietri, Charles (1976), Roma christiana. Recherches sur l'Église de Rome, son organisation, sa politique, son idéologie de Miltiade à Sixte III (311-440) (Bibliothèque des Écoles françaises d'Athènes et de Rome, 224), Rome: École française de Rome.

Prinzivalli, Emanuela (2010), 'La lettera di Clemente ai Corinzi', in Emanuela Prinzivalli and Manlio Simonetti (eds), Seguendo Gesù. Testi cristiani delle origini, I (Lorenzo Valla), Milano: Arnoldo Mondadori, 77-275, 425, 449-541.

Revillout, Eugène (1900-1914), 'Textes coptes. Extraits de la correspondance de St. Pésunthios évêque de Koptos et de plusieurs documents analogues (juridiques ou économiques)', in : Révue égyptologique, 9 (1900), 133-177; 10 (1902), 34-47; 14 (1914), 22-32.

Ross, Steven K. (2001), Roman Edessa. Politics and culture on the eastern fringes of the Roman Empire, 114-242 CE, London, New York: Routledge.

Schenk, Dietmar (2014), Kleine Theorie des Archivs, 2. überarbeitete Auflage. Stuttgart: Franz Steiner Verlag (1st ed. Stuttgart 2008).

Schmelz, Georg (2002), Kirchliche Amtsträger im spätantiken Ägypten nach den Aussagen der griechischen und koptischen Papyri und Ostraka (Archiv für Papyrusforschung, 13), Leipzig: De Gruyter.

Schulthess, Friedrich (ed.) (1908), Die syrischen Kanones der Synoden von Nicaea bis Chalcedon, nebst einigen zugehörigen Dokumenten (Abhandlungen der königlichen Gesellschaft der Wissenschaften zu Göttingen, Philologisch-historische Klasse, Neue Folge X/2), Berlin: Weidmannsche Buchhandlung.

Schwartz, Eduard (1936a), 'Über die Sammlung des Cod. Veronensis LX', in Zeitschrift für die neutestamentliche Wissenschaft, 35, 1-23.

Schwartz, Eduard (ed.) (1936b), Liberati Breviarium causae nestorianorum et eytychianorum, in Concilium universale chalcedonense, Volumen quintum: Collectio sangermanensis (Acta Conciliorum Oecumenicorum II/5), Berolini, Lipsiae: De Gruyter, 98-141. 
Schwartz, Eduard (1936c), 'Die Kanonessammlungen der alten Reichskirche', in Zeitschrift der Savigny-Stiftung für Rechtsgeschichte, 56 (69) - Kanonistische Abteilung 25, 1-144 (= Id. (1960), Gesammelte Schriften, IV: Zur Geschichte der alten Kirche und ihres Rechts, Berlin: De Gruyter, 159-275).

Schwartz, Eduard, and Theodor Mommsen (eds) (1999 [1903]) Eusebius Werke, II/1: Die Kirchengeschichte, Anastatic reimpression of the first edition with preface by Friedhelm Winkelmann (Die Griechischen christlichen Schriftsteller der ersten Jahrhunderte. Neue Folge 6), Berlin: Akademie Verlag.

Segal, Jakob B. (1970), Edessa: The 'Blessed City', Oxford: Clarendon.

Simonetti, Manlio (1975), La crisi ariana nel IV secolo (Studia Ephemeridis Augustinianum 10), Roma: Institutum Patristicum Augustinianum

Simonetti, Manlio (2010), 'Le lettere di Ignazio', in Emanuela Prinzivalli and Manlio Simonetti (eds), Seguendo Gesù. Testi cristiani delle origini, I (Lorenzo Valla), Milano: Arnoldo Mondadori 279-425, 542-628.

Stewart, Alastair C. (2014), The Original Bishops. Office and Order in the First Christian Communities, Grand Rapids, MI: Baker Academic.

Telfer, Walter (1943), 'The Codex Verona LX (58)', in Harvard Theological Review, 36, 169-246.

Traina, Giusto (1996), 'Archivi armeni e mesopotamici: la testimonianza di Movsēs Xorenac'i', in Marie-Françoise Boussac and Antonio Invernizzi (eds), Archives et sceaux du monde hellénistique - Archivi e sigilli nel mondo ellenistico, Torino, Villa Gualino, 13-16 Gennaio 1993 (Bulletin de correspondence hellénique, Supplément, 29), Paris: De Boccard, 49-63.

Turner, Cuthbert H. (1939), Ecclesiae Occidentalis Monumenta Iuris Antiquissima. Canonum et conciliorum graecorum interpretationes latinae, Tomi prioris fasciculi alterius pars quarta: Supplementum Nicaeno-alexandrinum sive Conciliorum Nicaeni et Serdicensis Sylloge a Theodosio Diacono [Carthaginensi] adservata secundum codicem unicum veronensem bibliothecae capitularis LX (58) saec. VII-VIII, Opus postumum, Oxonii: Clarendoniano.

Uthemann, Karl-Heinz (ed.) (1981), Anastasius the Sinaite, Viae dux (Corpus Christianorum Series Graeca, 8), Turnhout: Brepols.

Van der Vliet, Jacques (2002), Pisenthios de Coptos (569-632), moine, évêque et saint, in Marie-Françoise Boussac (ed.), Autour de Coptos - Actes du colloque organisé au Musée des Beaux-Arts de Lyon (17-18 mars 2000) (TOPOI, Orient-Occident, Supplément 3), Lyon, Paris: De Boccard, 61-72.

Van der Vliet, Jacques (2013), Les archives de Pesynthios: nouvelles découvertes, nouvelles questions, in Anne Boud'hors and Catherine Louis (eds), Études coptes XII. Quatorzième journée d'études (Rome 11-13 juin 2009) (Cahiers de la bibliothèque copte, 18), Paris: De Boccard, 263-269.

Van der Vliet, Jacques (2015), Le prêtre Marc, Psan et Pesynthios: un roseau miaphysite autour du monastère d'Épiphane, in Anne Boud'hors and Catherine Louis (eds), Études coptes XIII. Quinzième journée d'études (Louvain-la-Neuve, 12-13 mai 2011) (Cahiers de la bibliothèque copte, 20), Paris: De Boccard, 127-136.

Vandorpe, Katelijn (2009), 'Archives and Dossiers' in Roger S. Bagnall (ed.), The Oxford Handbook of Papyrology, Oxford: Oxford University Press, 216-255.

Van Nuffelen, Peter (2004), Un héritage de paix et de piété. Étude sur les histoires ecclésiastiques de Socrate et de Sozomène (Orientalia Lovaniensia analecta, 142), Leuven, Paris, Dudley, MA: Uitgeverij Peeters/Departement Oosterse Studies. 
Van Rompay, Lucas (1999), 'Jacob of Edessa and the Early History of Edessa', in Gerrit J. Reinink and Alex Klugkist (eds), After Bardaisan: Studies for H.J.W. Drijvers, Leuven: Peeters, 269285.

Verardi, Andrea A. (2016), La memoria legittimante: il Liber pontificalis e la Chiesa di Roma del secolo VI (Istituto storico italiano per il Medio Evo. Nuovi studi storici, 99), Rome: Istituto storico italiano per il Medio Evo.

Wipszycka, Ewa (1996), 'Il vescovo e il suo clero. A proposito di CPR V 11', in Ewa Wipszycka, Études sur le christianisme dans l'Égypte de l'antiquité tardive (Studia Ephemeridis Augustinianum, 52), Rome: Institutum Patristicum Augustinianum, 177-194.

Wipszycka, Ewa (2007), 'The Institutional Church', in Roger S. Bagnall (ed.), Egypt in the Byzantine World, 300-700. Cambridge, New York, Melbourne, Madrid: Cambridge University Press, 331-349.

Wipszycka, Ewa (2008), 'Les gens du patriarche alexandrin', in Christian Décobert, Jean-Yves Empereur (eds), Alexandrie médiévale 3 (Études alexandrines, 16), Cairo: Institut français d'archéologie orientale, 89-114.

Wipszycka, Ewa (2015), The Alexandrian Church. People and Institutions (Supplements to Journal of Juristic Papyrology, 25), Warsaw: University of Warsaw. 